\title{
Os ritos tridentinos na construção do Absolutismo: a importância de Luís XIV
}

\author{
Eduardo Gonçalves Almeida \\ dr.eduardodealmeida@protonmail.com
}

\section{Resumo}

A influência dos ritos tridentinos na sustentação do Absolutismo dos Estados Católicos do Antigo Regime é uma questão pertinente, apesar de se haver discorrido já abundantemente sobre esta forma de governo. As análises existentes sobre o Absolutismo não olharam de forma direta pelo prisma que propomos ao leitor com este trabalho. Centrados no caso francês de Luís XIV, tentaremos melhor compreender a estreita relação existente entre o Trono e o Altar na Europa do Antigo Regime, e de que modo esta osmose fortaleceu e assegurou até às revoluções liberais o domínio da sociedade europeia por estas duas instituições. Fá-lo-emos através da análise dos ritos religiosos, católicos, pós-tridentinos, e os próprios da "Sociedade de Corte" de Luís XIV. Desde tempos imemoriais a humanidade serviu-se de símbolos para expressar diferentes realidades e formas de legitimar o exercício do poder. Dos deuses Faraós, passando pelos Augustos da Antiguidade sabemos que a religião era absolutamente fundamental e indispensável e, com ela, se articulavam e legitimavam formas de poder político. Que papel desempenharam os ritos católicos na construção do ícone máximo do Absolutismo europeu?

Palavras chave: Absolutismo; Luís XIV; O Trono e Altar; Igreja Católica.

\begin{abstract}
The influence of the Tridentine rites in sustaining the Absolutism of the Catholic States of the Ancien Regime is a pertinent question, despite the fact that this form of government has already been abundantly discussed. The existing analyzes on Absolutism did not look directly at the prism that we propose to the reader with this work. Centered on the French case of Louis XIV, we will try to better understand the close relationship between the Throne and the Altar in Europe under the Ancien Regime, and how this osmosis strengthened and ensured until the liberal revolutions the domination of European society by these two institutions. We will do this through a particular prism: that of religious, Catholic, post-Tridentine rites, and those of Louis XIV's "Court Society". Since times immemorial, humanity has used symbols to express different realities and ways to legitimize the exercise of power. From the Pharaoh gods, through the Augustus of Antiquity, we know that religion was absolutely fundamental and indispensable and articulated and legitimized forms of political power. The study of the relationship between ecclesiastical rites and those of a monarchy in times of affirmation of Absolutism, in the final centuries of the Modern Era, emerges as necessary in this context. Therefore, this paper seeks to answer the following question: what role did Catholic rites play in the construction of the maximum icon of European Absolutism?
\end{abstract}

Keywords: Absolutism; Louis XIV; The Throne and the Altar; Catholic church. 


\section{Introdução}

A propósito do Absolutismo, já muito se escreveu desde a História à Sociologia. Se mencionamos Luís XIV, ainda mais abrangente e volumosa é a oferta de estudos e análises científicas. Dos autores consagrados destacaríamos, da escola "Anglo Saxónica”, Peter Burke: A construção de Luís XIV ${ }^{1}$, Peter Campbell: Luís XIV ${ }^{2}$; Richard Bonney: O Absolutismo ${ }^{3}$; da escola Francesa Biet Christien: Les miroirs du soleil: le roi Louis XIV et ses artistes ${ }^{4}$; Ernest Lavisse: Louis XIV. La Fronde. Le Roi. Colbert. Histoire de France ${ }^{5}$; Robert Mandrou: Louis $X I V$ en son temps ${ }^{6}$; e claro, Norbert Elias na sua celebérrima obra: $A$ sociedade de corte $^{7}$, entre outras que nos obrigou o presente estudo a consultar.

Contudo, o trabalho que a seguir apresentamos pretende olhar para estas duas realidades de uma forma nova. À medida que fomos lendo e analisando o período moderno, deparamonos com um conjunto de acontecimentos, que apesar de espaçados entre si se influenciaram de maneira inequívoca. Neste sentido, retivemos que seria importante estabelecer uma análise rigorosa das relações entre os rituais da Igreja Católica pós Trento e os rituais usados pelos príncipes cristãos para a construção de um regime centralizado. Focados no caso francês na época de Luís XIV e na documentação do Concílio Tridentino, este trabalho apresenta uma análise centrada nas demonstrações de poder através dos sinais externos usados pela autoridade religiosa e temporal. Para o efeito, consultamos algumas obras relacionadas com o barroco e os cerimoniais, mas nada encontramos desta correlação que nos propusemos estudar. Apesar disso, literaturas como A cultura do Barroco $^{8}$ de José Maravall, As liturgias políticas ${ }^{9}$ de Claude Rivière, $A$ arte clássica e o barroco $^{10}$ de Piere Cabanne, foram oportunas no sentido de verificarmos, com estes autores, a consolidação da importância do estilo barroco como cenário litúrgico.

Ao longo deste estudo iremos analisar um conjunto de interligações entre o Trono e o Altar que contribuíram, no nosso entender, para a afirmação simultânea do proselitismo Católico e, por outro lado, do direito divino dos reis, através de um intenso e elaborado ritual. Desde a etiqueta, passando pelas celebrações religiosas, até ao rito de coroação dos reis de França, muitas foram as estratégias da sociedade Moderna para assegurar a sobrevivência de dois poderes, numa

\footnotetext{
${ }^{1}$ BURKE, Peter - A construção de Luís XIV. Casal de Cambra: Caleidoscópio, 2007.

${ }^{2}$ CAMPBELL, Peter - Luís XIV. Lisboa: Editorial Presença, 2009.

${ }^{3}$ BONNEY, Richard - O Absolutismo. Mem Martins: Publicações Europa América, 1989.

${ }^{4}$ CHRISTIAN, Biet - Les miroirs du soleil: le roi Louis XIV et ses artistes. Paris: Gallimard, 2000.

${ }^{5}$ LAVISSE, Ernest - Louis XIV. La Fronde. Le Roi. Colbert. Histoire de France. Normandia: Des Equateurs, 2013.

${ }^{6}$ MANDROU, Robert - Louis XIV: en son temps: 1661-1715. Paris: Presses Universitaires de France, 1973.

${ }^{7}$ ELIAS, Norbert - A sociedade de corte. Lisboa: Editorial Estampa, 1987.

${ }^{8}$ MARAVALL, José António - A cultura do Barroco. Lisboa: Instituto superior de novas profissões, 1997.

${ }^{9}$ RIVIÈRE, Claude - As liturgias políticas. Rio de Janeiro: Imago Editora, 1989.

${ }^{10}$ CABANNE, Pierre - A arte clássica e o barroco. Lisboa: Edições 70, 2001.
} 
época de expansionismo europeu para além das fronteiras da Europa e em que o humanismo e o protestantismo colocariam em causa os poderes consagrados.

A escolha do Rei Sol como objeto de análise decorre da importância que este monarca assumiu como modelo para os seus homólogos europeus ${ }^{11}$. Interessa-nos perceber se afinal o Catolicismo e a religião tiveram algo a dizer, ou se de facto Luís XIV era, como alguns dizem, um monarca "absoluto", independente do exercício de outras "autoridades", nos alvores de um tempo que mais tarde ficaria marcado por sangrentas revoluções. Desde os Imperadores Augustos $^{12}$ que a Europa não assistia a uma manifestação tão exuberante e "dramática"13 dos líderes políticos, como aquela que ocorrerá no Antigo Regime com os Estados Absolutos. Esta realidade, manifesta-se na arquitetura, música, pintura, panegíricos, numismática entre tantas outras artes, influenciadas por um novo estilo artístico ${ }^{14}$.

A arte do espetáculo e a afirmação externa, através do ritual, é algo que ressalta quando falamos de Luís XIV ${ }^{15}$, quando pensamos na corte de Versalhes, mas também quando imaginamos o ritual Católico longo e ostensivo emanado das reformas tridentinas. Afinal, qual o sentido de todas estas realidades exteriores? Uma questão estética? Uma questão funcional? Como podemos interpretar a colossal herança artística deste período desde as telas de Le Brun aos manuais litúrgicos do Concílio de Trento? Que relação têm entre si? Na verdade, o culto do poder e a sua demonstração torna-se inequivocamente visível através de expressões que hoje entendemos como exageradas, mas de que subliminarmente somos herdeiros inconscientes.

\section{A Reforma Católica e o nascimento do Barroco}

O estilo barroco, que irá florescer em Itália no início do século XVII, ganha esta designação, segundo Pierre Cabanne, do espanhol barrueco "que designa uma pedra irregular"16. Esta terminologia parece ser adequada quando pensamos no Barroco como extravagante, sumptuoso e repleto de contorções com o intuito de representar o infinito e o magistral. É certamente uma tendência que tendo por base o clássico foi sem sombra de dúvidas o seu opositor e teve, por isso, o classicismo

\footnotetext{
11 “A partir do Renascimento, a importância da corte foi sempre aumentando em todos os países da Europa e... é verdade que a organização das cortes europeias dos séculos XVII e XVIII se inspirou basicamente na da corte francesa, designadamente na de Luís XIV.” (ELIAS, Norbert - A sociedade de corte. Lisboa: Editorial Estampa, 1987, pp. 13-14).

12 "A ideia de um Rei Sol seguiu os rastos do mundo Antigo." (BURKE, Peter - A construção de Luís XIV. Casal de Cambra: Caleidoscópio, 2007, p. 12).

${ }^{13}$ No sentido da exposição e afirmação pública do poder.

14 "Os retratos equestres e as estátuas influenciaram-se uns aos outros, as medalhas foram reproduzidas em baixo-relevo e os elogios do rei foram escritos em forma de descrições das pinturas... Com esta grande quantidade de media, é difícil decidir se as imagens visuais ilustraram os textos ou vice-versa. O importante é que, certamente, eles se influenciaram e reforçaram reciprocamente." (BURKE, Peter - A construção de Luís XIV. Casal de Cambra: Caleidoscópio, 2007, p. 26).

15 "Le faste et la splendeur qui environnent les rois font une partie de leur puissance." (MONTESQUIEU, Charles Louis de - Do Espirito das Leis. In Coleção Os Pensadores - Montesquieu. São Paulo: Abril cultural, 1973, p. 58).

${ }^{16}$ CABANNE, Pierre - A arte clássica e o barroco. Lisboa: Edições 70, 2001, p. 12.
} 
como o seu maior crítico. Surgido no interior da Igreja Católica em tempos de Reforma, este estilo rapidamente foi cobiçado e utilizado para reforçar a glória dos Tronos e dos Príncipes.

O estilo Barroco também serviu para o suporte sumptuário da afirmação dos Reis, dos príncipes, de Nobres, desde D. João V a Luís XIV, Reis espanhóis, Imperadores, etc. Mas nem todos se afirmaram de igual maneira, indo alguns buscar decorações mitológicas e laicas, enquanto outros se fizeram mecenas exuberantes de encomendas religiosas, num sentido competitivo. Foi este o caso de D. João V, em Portugal ${ }^{17}$.

É impossível falar do Barroco sem mencionar o papel determinante que teve a Igreja pós Tridentina, tanto na sua elaboração, bem como no seu ideário de superioridade e proselitismo religioso. Impunha-se nesse tempo o combate ao Protestantismo, não só pelas palavras, mas sobretudo pelas imagens ${ }^{18}$.

O militantismo e triunfalismo da Igreja da Contrarreforma exigem efeitos de força, uma retórica do espetáculo na decoração, uma proliferação por vezes excessiva das formas, uma riqueza exuberante do colorido que, para provocar a emoção, não hesitam em recorrer aos efeitos ilusionistas ${ }^{19}$.

Os autores que exararam sobre este movimento artístico são unânimes nas suas explicações sobre o intuito que levou ao seu aparecimento. Há uma razão que se poderá destacar como a mais influenciadora e a mais importante, que na nossa análise entendemos como "razão litúrgica”. Era necessário dotar a liturgia da Igreja de um esplendor e eloquência visual, auditiva e sensível, capaz de colocar o público dos "espetáculos litúrgicos" na crença profunda de que a Igreja Católica era a única verdadeira religião e que esta gozava de uma sobrenatural infalibilidade. "A decoração sobrecarrega-se, as visões celestiais ocupam a abóbada, as estátuas ganham movimento, enquanto as paredes se cobrem com uma policromia de mármores, bronzes dourados, pórfiros e estuques. Nestas espécies de teatros, as celebrações litúrgicas ganham um aspeto de verdadeiros espetáculos." ${ }^{20}$ De facto assim foi, e ainda hoje podemos observar esta realidade, desde os edifícios aos livros litúrgicos que continham o ritual barroco e solene da "Cristandade Tridentina". Inclusivamente os clérigos eram admoestados a realizar da forma mais perfeita e rigorosa, a execução dos ofícios, com especial destaque para o "Santo Sacrifício da Missa"21.

\footnotetext{
${ }^{17}$ I Congresso Internacional do Barroco, I volume: atas. Porto: Universidade do Porto. Reitoria, 1991, p. 155.

18 “Ao Concílio não bastava, porém, fazer uma afirmação solene de fé na doutrina eucarística tradicional da Igreja. Impunha-se ir mais além frente aos ataques dos Reformadores Protestantes..." (I Congresso Internacional do Barroco, II volume: actas. Porto: Universidade do Porto. Reitoria, 1991, pp. 21.)

${ }^{19}$ CABANNE, Pierre - A arte clássica e o barroco. Lisboa: Edições 70, 2001, p. 12.

${ }^{20}$ CABANNE, Pierre - A arte clássica e o barroco. Lisboa: Edições 70, 2001, p. 14

21 "Quanto ao cuidado que deve ser tomado para que se celebre, com todo o culto e veneração que pede a religião sobre o santo sacrifício as Missa, facilmente poderá ser compreendido por qualquer pessoa que considere o que diz a Sagrada Escritura: «maldito aquele que executa com negligência a obra de Deus». E se necessariamente confessamos que a nenhuma outra obra podem manejar os fiéis cristãos, tão santa e tão divina como o tremendo mistério no qual todos os dias é oferecida a Deus em sacrifício, pelos sacerdotes no altar, aquela hóstia vivificante, pela qual nós fomos reconciliados com Deus Pai, é muito importante que seja observado que se deve colocar todo o cuidado e diligência em executá-la, com maior inocência e pureza interior de coração e demonstração exterior de devoção e piedade que seja possível.” (Igreja Católica - Concílio Tridentino, Sessão XXII).
} 
No estudo que fizemos das fontes litúrgicas, pudemos reter como solene definição, aquela do Concílio Tridentino que explica a importância do ritual no que respeita à "manifestação da majestade do culto".

Sendo tal a natureza das pessoas que não se possa elevar facilmente a meditação das coisas divinas sem auxílios ou meios extrínsecos, nossa piedosa Mãe, a Igreja, estabeleceu por estes motivos, certos rituais a saber: que algumas palavras da Missa sejam ditas em voz baixa, e outras com voz mais elevada. Além disso, se valeu de cerimónias como bênçãos místicas, luzes, incensos, ornamentos e outras muitas coisas deste género, por ensinamentos e tradição dos Apóstolos, com a finalidade de recomendar por este meio a majestade de tão grande sacrifício e excitar os ânimos dos fiéis por estes sinais visíveis de religiosidade e piedade à contemplação dos altíssimos mistérios que estão ocultos neste sacrifício ${ }^{22}$.

Assim, todas as artes foram absorvidas pelo novo estilo e que se verificava na pintura, escultura, arquitetura, música, ourivesaria entre tantas outras. Estavam assim fortificadas as raízes de uma nova era, a que iria lançar os artistas europeus numa corrida ao fausto, ao impressionante, ao megalómano.

Desta forma, e para enfatizar esta crença, o concílio de Trento estipulará um anátema a todos aqueles que de alguma forma ousarem contestar as disposições emanadas pela Igreja: "Se alguém disser que as cerimónias, vestimentas, e sinais externos de que usa a Igreja Católica na celebração das Missas, são muito mais incentivos de impiedade que obséquios piedosos, seja excomungado." ${ }^{23}$ Este parágrafo é um resumo perfeito do propósito do concílio tridentino a este respeito. Como já dissemos, o Barroco, nascido no interior da Igreja, rapidamente será utilizado pelos príncipes cristãos com o intuito de fazer sobressair o seu poder. Neste sentido, partilhamos o pensamento do historiador de Arte Andreas Prater que afirma o barroco como "uma forma muito elaborada de dominação das massas.":

O barroco, essa época em que o absolutismo coabita com as Luzes, é considerado como o último grande estilo europeu. Visto, durante muito tempo, como o "dialeto copioso do Renascimento", o barroco opõe à medida clássica um complexo dinâmico de formas e de expressões múltiplas. Assiste-se à oposição entre alegria de viver mundana e sensualidade distinta, espiritualidade religiosa e austeridade ascética, abundante produção formal e rigorismo de regras. Ao mesmo tempo, o ilusionismo faz entrar na arte o teatral e o cénico. O próprio teatro, o cerimonial e as festas de corte não são apenas a expressão da vitalidade barroca, eles apresentam-se também como uma forma muito elaborada de dominação das massas ${ }^{24}$.

Destacaríamos neste texto a afirmação de que este movimento artístico seria o "dialeto copioso do renascimento". De facto, pode-se verificar esta premissa: o barroco sempre se caracterizou como herdeiro do Renascimento no que diz respeito à sua base de edificação, visível sobretudo na arquitetura e na pintura. Já Vasari dizia na sua obra Le vite de' più eccellenti pittori, scultori e architettori: "posso dizer com toda a segurança que a arte realizou tudo o que é permitido a um imitador de natureza e se elevou tão alto que, hoje, é mais de recear o seu

\footnotetext{
${ }^{22}$ IGREJA CATÓLICA - Concílio Tridentino, Sessão XXII, Cânon V.

${ }^{23}$ IGREJA CATÓLICA - Concílio Tridentino, Sessão XXII, Cânon VII.

${ }^{24}$ PRATER, Andreas - A pintura do Barroco. Lisboa: Taschen, 1997, p. 9.
} 
declínio que esperar novos progressos" 25 . É interessante pensá-lo desta forma, pois foi com o Renascimento que o Homem europeu quis recuperar o ideário da Antiguidade. O próprio Maquiavel, que iria tecer várias reflexões inerentes ao centralismo do poder, coloca este novo período da história em oposição ao medieval, no sentido de regressar a um passado áureo que se perdera com o tempo: "No umbral me despojo da indumentária quotidiana, suja e embarrada, e me ponho em roupas régias e curiais, e, vestido assim dignamente, entro nas antigas cortes dos homens Antigos, onde, alegremente acolhido, me alimento dessa comida que «solum» me pertence e para a qual nasci" ${ }^{26}$. Deste modo, as roupas sujas e embarradas representariam o período medieval e os seus conflitos políticos, as roupas régias e curiais dos homens "Antigos", seriam a recuperação dos saberes clássicos e do governo estável dos Imperadores Romanos. Sabemos que grande parte dos monarcas do Antigo Regime vai imitar, na medida das suas possibilidades, as funções imperiais, inclusivamente vai colocar nos seus epítetos o título de "Augusto". Vejase como grande exemplo disto o Rei Luís XIV, de que falaremos mais adiante.

A osmose entre o temporal e o espiritual manifestou-se de forma inequívoca através do barroco. De um lado, assistimos à sua utilização para fortificar a crença, e do outro para consolidar o poder régio e dotá-lo de um carácter divino e sobrenatural. Mais que o próprio Renascimento, este novo estilo condiz com a pretensão de novos "Imperadores" ainda mais sublimes pela sua sabedoria, força militar e até pela sua devoção religiosa. Não é também por acaso que as doutrinas do "direito divino dos reis", tanto no meio Católico com Bossuet ${ }^{27}$, como no meio protestante com Hobbes, se espalharão rapidamente. Os monarcas saberão utilizar as filosofias do direito divino com a arte teatral barroca ${ }^{28}$ para terminar definitivamente com a limitação dos seus poderes no governo dos seus povos.

\section{O Altar e o Trono}

\subsection{As liturgias do Altar}

Julgamos dever confiar este trabalho a uma comissão de homens eruditos. Estes começaram por cotejar cuidadosamente todos os textos com os antigos de nossa Biblioteca Vaticana e com outros, quer corrigidos, quer sem alteração, que foram requisitados de toda parte. Depois, tendo consultado os escritos dos antigos e de autores aprovados, que nos deixaram

\footnotetext{
${ }^{25}$ VASARI, Giorgio - Le Vite De' Piu Eccellenti Pittori, Scultori et Architettori Scritte.

${ }^{26}$ MAQUIAVEL, Nicolau - A arte da guerra. Brasil: Editora Campus, 2003.

27 "É por isto que nós consideramos o trono real não como o trono de um homem, mas como o trono do próprio Deus. Decorre de tudo isto que a pessoa dos reis é sagrada e que atentar contra ela é um sacrilégio." (BOSSUET, Jacques Benigne - Politica estratta dalle proprie parole della sacra scrittura. Veneza: Grabiello Ertz, 1714).

28 "O barroco é um teatro. Utilizou muitas vezes a cenografia, mas nunca, como com os Bibiena, arquitetos, pintores e decoradores que trabalharam em toda a Europa, tinha inspirado a encenação lírica do espaço..." CABANNE, Pierre - A arte clássica e o barroco. Lisboa: Edições 70, 2001, p. 82.
} 
documentos relativos à organização destes mesmos ritos, eles restituíram o Missal propriamente dito à norma e ao rito dos Santos Padres $^{29}$.

O Papa Pio V na sua bula Quo Primum Tempore sobre o Missal Romano, deixa claro que a sua revisão e estrutura ficaria a cargo de um "conjunto de eruditos", ou seja, o Papa tridentino levaria a cabo a missão de preservar e organizar da melhor forma $\operatorname{possível}^{30}$ as orações litúrgicas da Igreja que remontavam a tempos ancestrais. Ao contrário do que se possa pensar, o concílio de Trento não reformou a liturgia no sentido que hoje empregamos o termo. A ação do Concílio foi sobretudo a de aliar os rituais a uma complexa estrutura externa de nobreza, enfatizando o carácter sobrenatural dos sacramentos. "Além disso, se valeu de cerimónias como bênçãos místicas, luzes, incensos, ornamentos e outras muitas coisas deste gênero, por ensinamentos e tradição dos Apóstolos"31, e ainda:

Quando os fiéis recebem a Eucaristia sacramentalmente, sempre foi costume da Igreja de Deus que estes leigos tomem a comunhão da mão do sacerdote, e que os sacerdotes, quando celebram, se comunguem a si mesmos. Esse costume deve ser mantido com muita razão por vir de uma tradição apostólica ${ }^{32}$.

Tal como mais tarde o trono se servirá da "tradição" para enfatizar o seu poder de direito divino, a Igreja no Concílio de Trento evoca a tradição apostólica como o fundamento das suas decisões em matéria de fé e liturgia. Esta dimensão é inequívoca e pode largamente ser encontrada na documentação. Isto significa que o Concílio não quer inovar ou ensinar algo novo, mas manter a tradição. Posto isto, convém que olhemos para os diferentes ritos litúrgicos e compreendamos que daqui se segue um suporte muito concreto para moldar todo um pensamento social assente na "Ordem" e na "Hierarquia."

A liturgia católica, como a conhecemos nos manuais tridentinos, está repleta de um conjunto imenso de ritos maiores e menores, que visam transmitir um carácter sagrado aos ofícios que executam os clérigos. Esta dimensão vai-se tornando cada vez mais complexa à medida que a dignidade do Oficiante se faz presente. Deste modo, o rito da missa, por exemplo, oficiada por um Bispo, na designada missa pontifical, pode ser caracterizada visualmente como um assombro "barroco" de linguagem mística, seja pela quantidade dos ministros, seja pela grandeza e magnificência dos espaços do culto.

\footnotetext{
29 "Quare eruditis delectis viris onus hoc demandandum duximus: qui quidem, diligenter collatis omnibus cum vetustis Nostrae Vaticanae Bibliothecae, aliisque undique conquisitis, emendatis atque incorruptis codicibus; necnon veterum consultis ac probatorum auctorum scriptis, qui de sacro eorumdem rituum instituto monumenta Nobis reliquerunt, ad pristinam Missale ipsum sanctorum Patrum normam ac ritum restituerunt." (PIO V - Quo Primum Tempore).

30 "Quo primum tempore ad Apostolatus apicem assumpti fuimus, ad ea libenter animum, viresque nostras intendimus, et cogitationes omnes direximus, quae ad Ecclesiasticum purum retinendum cultum pertinerent, eaque parare, et Deo ipso adjuvante, omni adhibito studio efficere contendimus." [Desde que fomos elevados ao ápice da Hierarquia Apostólica, de bom grado aplicamos o nosso zelo e as nossas forças e dirigimos todos os nossos pensamentos no sentido de conservar na sua pureza tudo o que diz respeito ao culto da Igreja; o que nos esforçamos por preparar e, com a ajuda de Deus, realizar com todo o cuidado possível.] (PIO V - Quo Primum Tempore).

${ }^{31}$ IGREJA CATÓLICA - Concílio Tridentino, Sessão XXII, Cânon V.

32 IGREJA CATÓLICA - Concílio Tridentino, Sessão XIII, Cânon VIII.
} 
Para termos uma melhor compreensão, as fontes dizem-nos que um bispo para a missa pontifical deverá revestir-se de 12 alfaias diferentes para execução dos ritos: "1. Ad amictum; 2. Ad Albam; 3. Ad cingulum; 4. Crucem pectoralem; 5. Ad Stolam; 6. Ad Tunicellam; 7. Ad Dalmaticam; 8. Ad Chirothecas; 9. Ad Planetam; 10. Ad Mitram; 11. Ad anulum; 12. Ad manipulum."33 Entre outras coisas, sabemos que ao todo, numa cerimónia como a pontifical, só o celebrante deve obedecer a mais de novecentas rubricas de forma rigorosa. ${ }^{34} \mathrm{O}$ Venerável Martinho de Chochem, padre e teólogo alemão do século XVII, descreveu o número de alguns destes mesmos ritos:

O sacerdote persigna-se dezasseis vezes; volta-se seis vezes para o povo; beija o altar oito vezes; levanta os olhos para o céu onze vezes. Dez vezes bate no peito, e dez vezes ajoelhase; junta as mãos cinquenta e quatro vezes; faz vinte e uma inclinações com a cabeça e sete com os hombos; faz inclinação profunda oito vezes; benze trinta e três vezes a oferta com o sinal da cruz; põe vinte e nove vezes as duas mãos sobre o altar; catorze vezes reza com os braços estendidos e trinta e seis vezes juntando as mãos; põe as mãos juntas sobre o altar sete vezes; nove vezes coloca a mão esquerda só, inteiramente; onze vezes coloca-a sobre o peito; oito vezes levanta as duas mãos para o céu; onze vezes ora em voz baixa e treze em voz alta; descobre e cobre o cálix cinco veze, e muda de lugar vinte vezes. Além d'estas trezentas e cinquenta cerimónias, o sacerdote deve observar ainda cento o cinquenta, ao todo quinhentas ${ }^{35}$.

Para o efeito, o Papa Pio V decretara em perpetuidade todas estas cerimónias sob pena

de "indignação de Deus", àqueles que ousassem violar o seu decreto:

E a fim de que todos, e em todos os lugares, adotem e observem as tradições da Santa Igreja Romana, Mãe e Mestra de todas as Igrejas, decretamos e ordenamos que a Missa, no futuro e para sempre, não seja cantada nem rezada de modo diferente do que esta, conforme o Missal publicado por Nós, em todas as Igrejas (...) Se alguém, contudo, tiver a audácia de atentar contra estas disposições, saiba que incorrerá na indignação de Deus Todo-poderoso e de seus bem-aventurados Apóstolos Pedro e Paulo ${ }^{36}$.

\footnotetext{
${ }^{33}$ IGREJA CATÓLICA - Missale Romanum ex decreto Sacrosancti Concilii Tridentini. Tours: Sumptibus et typis Mame (Sacrae Rituum Congregationis Typographorum), 1957, p. XLVIII.

34 "Acrescentando a estas cerimonias as quatrocentas rubricas prescritas, verificareis que o sacerdote que celebra a santa Missa: conforme o rito romano, está obrigado, sob pena de pecado, a novecentas obrigações. Cada uma destas obrigações tem a significação espiritual, e cada uma tende a fazer cumprir digna e piedosamente o santo Sacrifício da Missa. Pelo que o Papa Pio V ordenou formalmente que todos, Cardeais, Arcebispos, Bispos, Prelados e simples sacerdotes dissessem a Missa desta maneira, sem nada mudar nem: acrescentar ou diminuir um ponto sequer." (COCHEM, Martinho - Explicação da Santa Missa. Bahia: Tipografia de São Francisco, 1914, p. 41).

${ }^{35}$ COCHEM, Martinho - Explicação da Santa Missa. Bahia: Tipografia de São Francisco, 1914, pp. 40-41.

36 "Ut autem a sacrosancta Romana Ecclesia, ceterarum ecclesiarum matre et magistra, tradita ubique amplectantur omnes et observent, ne in posterum perpetuis futuris temporibus in omnibus Christiani orbis Provinciarum Patriarchalibus, Cathedralibus, Collegiatis et Parochialibus, saecularibus, et quorumvis Ordinum, monasteriorum, tam virorum, quam mulierum, etiam militiarum regularibus, ac sine cura Ecclesiis vel Capellis, in quibus Missa conventualis alta voce cum Choro, aut demissa, celebrari juxta Romanae Ecclesiae ritum consuevit vel debet alias quam juxta Missalis a nobis editi formulam decantetur, aut recitetur, etiamsi eaedem Ecclesiae quovis modo exenptae, Apostolicae Sedis indulto, consuetudine, privilegio, etiam juramento, confirmatione Apostolica, vel aliis quibusvis facultatibus munitae sint; nisi ab ipsa prima institutione a Sede Apostolica adprobata, vel consuetudine, quae, vel ipsa institutio super ducentos annos Missarum celebrandarum in eisdem Ecclesiis assidue observata sit: a quibus, ut praefatam celebrandi constitutionem vel consuetudinem nequaquam auferimus; sic si Missale hoc, quod nunc in lucem edi curavimus, iisdem magis placeret, de Episcopi, vel Praelati. Capitulique universi consensu, ut quibusvis non obstantibus, juxta illud Missas celebrare possint, permittimus; ex aliis vero omnibus Ecclesiis praefatis eorumdem Missalium usum tollendo, illaque penitus et omnio rejiciendo, ac huic Missali nostro nuper editio, nihil unquam addendum, detrahendum, aut immutandum esse decernendo, sub indignationis nostrae poena, hac nostra perpetuo valitura constitutione statuimus et ordinamus... Si quis autem hoc attentare praesumpserit, indignationem omnipotentis Dei, ac beatorum Patri et Pauli Apostolorum ejus se noverit incursurum." (PIO V - Quo Primum Tempore).
} 
Podemos assim concluir a vontade puritana da Igreja Católica na época em guardar "religiosamente" os preceitos rituais, como forma de culto e instrução do povo.

Para além da missa, o clero estava obrigado à recitação de um número considerável de orações ao longo do dia, obrigando-o, assim, a ritualizar o seu quotidiano. Estas orações estavam contidas num livro litúrgico chamado Breviário e pretendia ser a continuação da oração do "Santo Sacrifício". O Breviário era constituído pelas Matinas, Laudes, Prima, Tércia, Sexta, Noa, Véspera e Completas ${ }^{37}$, era obrigatório a todos os clérigos de ordens maiores. À imagem do Antigo Testamento, o sacerdote católico era o homem do culto e todas estas orações mais a missa, eram a forma de obrigar os clérigos a cumprir o seu dever de rezar, bem como afastá-lo da ociosidade que a Igreja considerava inimiga da alma.

Quando pensamos numa sociedade de ordens tripartida e trifuncional como a dos Estados Católicos do Antigo Regime, o dever de rezar era considerado o mais importante. Deste modo, a elite sacerdotal tinha o dever de o fazer, como o camponês de trabalhar a terra.

Não podemos viver todos na mesma condição. É necessário que uns comandem e os outros obedeçam. Os que comandam têm várias categorias ou graus: os soberanos mandam em todos os do seu reino, transmitindo o seu comando aos grandes, os grandes aos pequenos e estes ao povo. E o povo, que obedece a todos eles, está, por sua vez, dividido em várias categorias. No conjunto da sociedade, uns dedicam--se especialmente ao serviço de Deus, outros a defender o Estado pelas armas, outros a alimentá-lo e mantê-lo pelo exercício da paz. São as três Ordens ou estados gerais. Mas cada uma destas ordens está dividida em ordens subalternas, seguindo o exemplo da hierarquia celeste ${ }^{38}$.

Resta-nos por fim abordar a questão temporal inerente aos ritos eclesiásticos. Aqui é importante considerar que a Igreja funcionava como uma monarquia absoluta, cuja cabeça é o Papa. Até aqui percebemos onde os monarcas foram buscar a sua inspiração para a constituição do Absolutismo. Neste sentido uma das realidades que observamos através da liturgia, é a sua profunda e distinta hierarquia. É pela hierarquia que o poder eclesiástico constitui verdadeiros príncipes sagrados, que para além de conselheiros do poder temporal, exerciam as suas funções como verdadeiros senhores feudais:

Os eclesiásticos, por estas imunidades e pelas leis do direito canónico e pelos privilégios dos nossos Reis, se consideram uma certa monarquia cuja cabeça é o Papa, independente d'el Rei para obedecer-lhe e para servi-lo, nem com os seus bens nem com os seus domésticos; consideram-se superiores às justiças do reino e a todos os que os servem; que os bens que têm, e os tributos que não pagam, lhes são devidos como um tributo à Igreja, e não por favor e graça dos Reis ${ }^{39}$.

Esta dimensão é de suma importância, pois isto supostamente iria colidir com as pretensões absolutistas dos monarcas, realidade que apesar de algumas hostilidades nunca se constituiu como um ponto de rutura com a Igreja. O próprio Luís XIV, de quem falaremos de seguida, muito também

\footnotetext{
${ }^{37}$ IGREJA CATÓLICA - Breviarium Romanum ex decreto Sacrosancti Concilii Tridentini.

${ }^{38}$ LOYSEAU, Charles - Tratado das ordens e das dignidades.

${ }^{39}$ SANCHES, Ribeiro - Cartas sobre a Educação da Mocidade, 1760.
} 
pela sua cultura religiosa, jamais ousou questionar ou colocar-se acima do poder espiritual, antes soube através dele reforçar a ideia de príncipe cristão de direito divino. Vemos inclusivamente que aqueles príncipes que entraram em rutura com o Catolicismo a partir do Renascimento, como por exemplo Henrique VIII, jamais conseguiram afirmar um poder absoluto nos seus tronos.

Fig. 1 - Horace Vernet - "Papa Pio VIII em São Pedro, na Sedia Gestatória.”, 1829

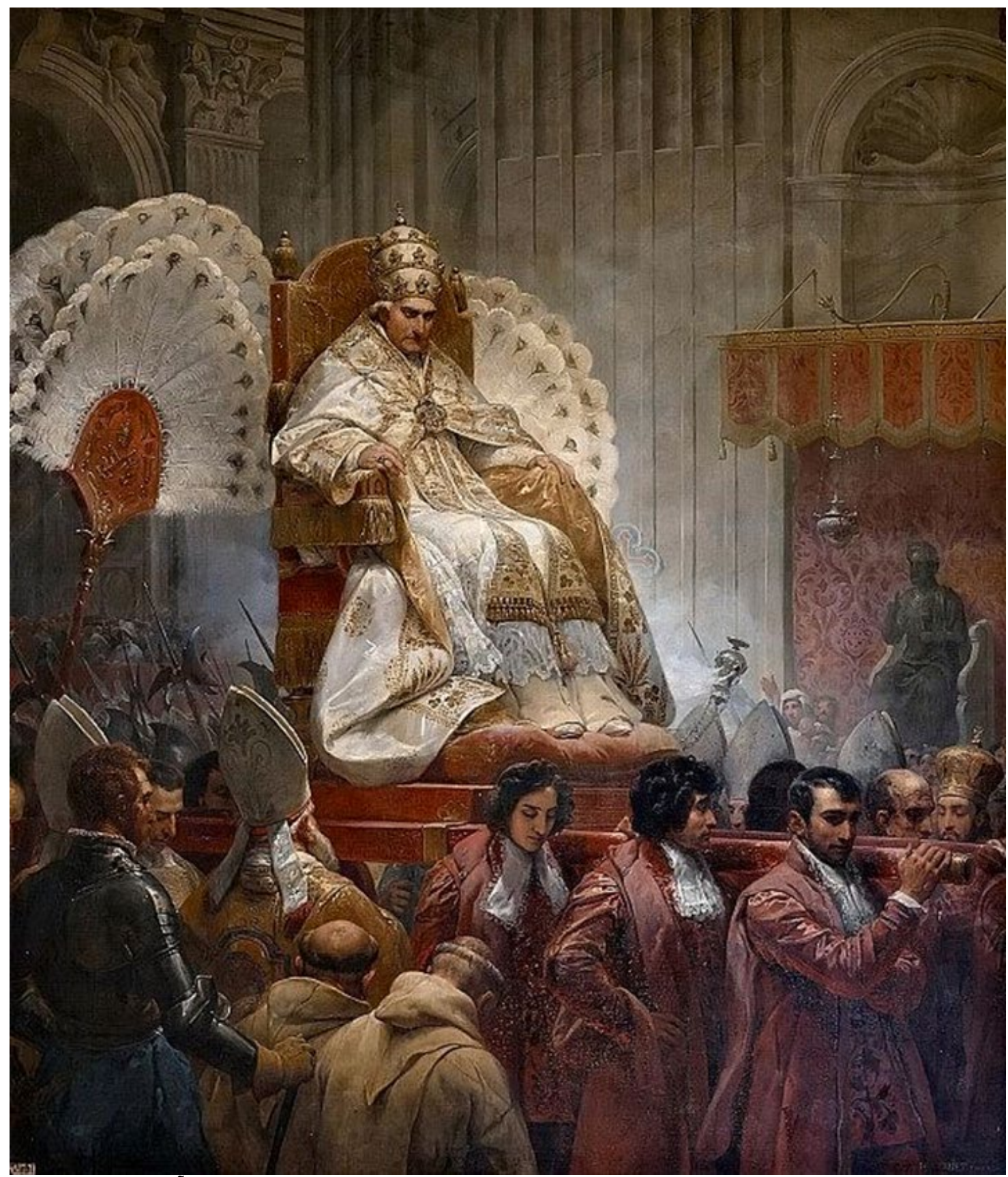

DESCRIÇÃO: óleo sobre tela, 385 x 329 cm. FONTE: Châteaux de Versailles et de Trianon, Versailles.

Neste retrato vemos o Papa com a tríplice tiara, símbolo do seu poder absoluto sobre a Igreja e sobre o mundo. É transportado na Sedia juntamente com os flabelos, sinal distintivo dos Imperadores. O Sumo Pontífice tinha também o título de pai dos reis. 
Fig. 2 - Philippe de Champaigne - "O cardeal de Richelieu”, 1585-1644

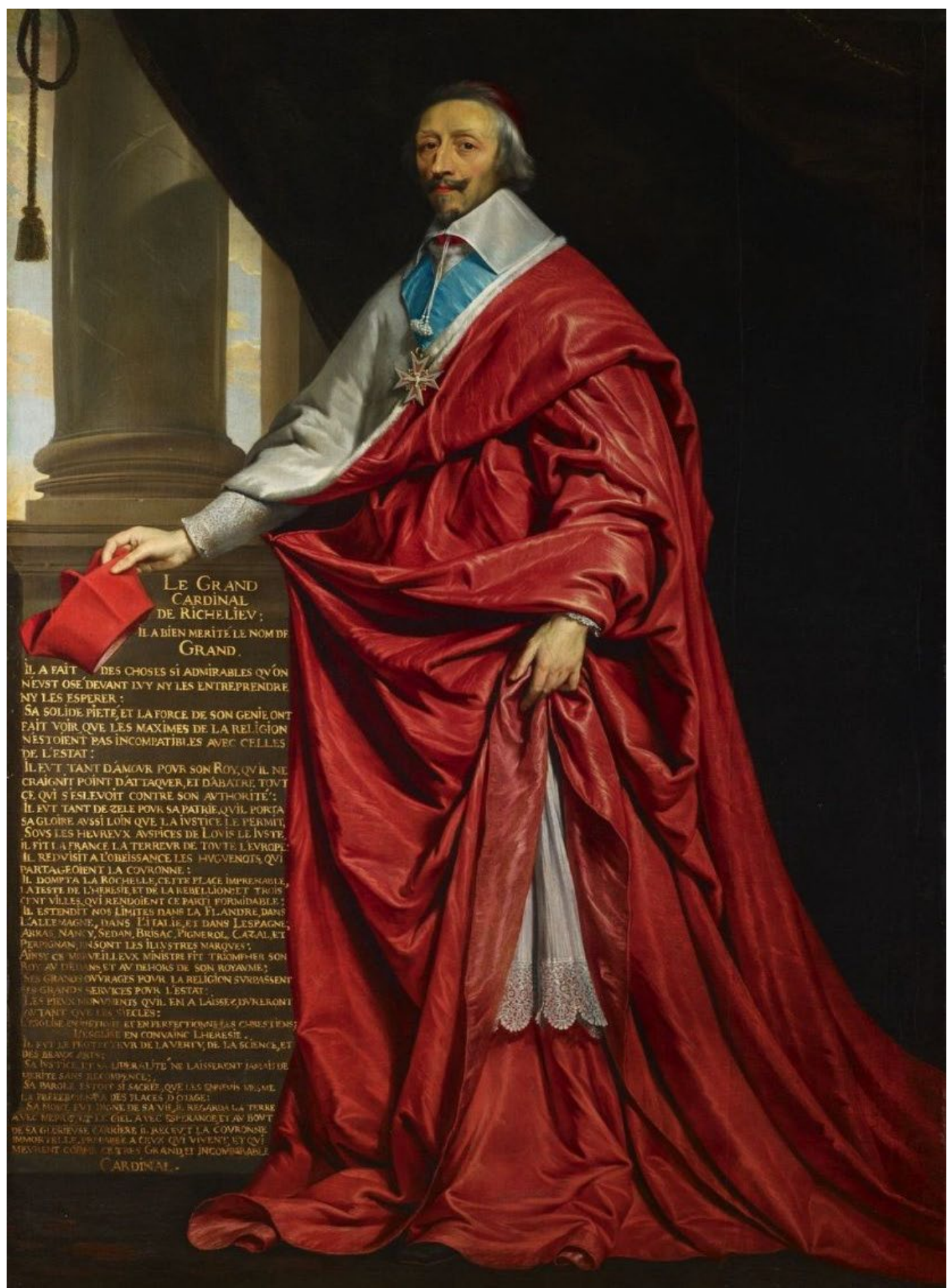

DESCRIÇÃO: óleo sobre tela, 207 x 146 cm. FONTE: The Royal Collection Trust.

O primeiro executor do absolutismo e precursor de Luís XIV. Richelieu é um símbolo da influência do clero nos assuntos do Estado no seu tempo. Aqui aparece de forma imponente com a sua capa magna encarnada, símbolo da realeza de Cristo e do seu poder temporal enquanto Cardeal; o barrete símbolo de jurisdição, sobrepeliz barroca de renda e o colar da ordem do Espírito Santo. 


\subsection{As liturgias do Trono}

O cerimonial litúrgico das monarquias do Antigo Regime, sobretudo no caso francês, pode facilmente comparar-se com os rituais católicos, onde aliás muito da sua ritualização era parte integrante das cerimónias do Trono. A monarquia ao tempo de Luís XIV é o exemplo mais sublime desta realidade.

O essencial das liturgias políticas sob a monarquia do antigo regime (coloco entre parênteses as festas populares e religiosas) está centrado no príncipe ou no senhor. Ao mesmo tempo que exalta a potência de um soberano, a ritualização das relações hierárquicas e das trocas de serviços intenta celebrar, além da continuidade de um poder, a estabilidade das instituições de uma sociedade onde cada um representa o seu papel ${ }^{40}$.

A principal função do cerimonial régio e cortesão deste período, para além de destacar a figura régia como sagrada, é secundariamente imitar a corte celeste, regulada também ela e segundo os teólogos, por uma hierarquia sagrada, onde os coros dos anjos se distinguem pelo grau de proximidade a Deus. Numa sociedade fortemente religiosa, a vontade de Deus em colocar cada qual no seu lugar através do nascimento era inquestionável.

Mascarando temporariamente os conflitos políticos, a cerimónia pretende mostrar a imagem de um universo humano, cósmico e religioso coerente, onde cada elemento permanece distante do outro de acordo com a vontade de Deus, pois a secularização da sociedade não está efetuada ${ }^{41}$.

É nesta osmose entre religiosidade e profano que se deve interpretar as ações régias deste período. Segundo Luís XIV:

Como é importante para o público ser governado por uma só pessoa, também é importante para ele que aquele que desempenha essa função esteja de tal modo acima dos outros que ninguém se possa confundir ou comparar com ele e não se pode, sem lesar todo o corpo do Estado, retirar à sua cabeça os sinais de superioridade, e mesmo os mais ínfimos, que a distinguem dos seus membros ${ }^{42}$.

\subsubsection{A importância da etiqueta como liturgia}

“A etiqueta não se reduz a mero repertório do que devemos ou não fazer. É preciso que os gestos e palavras considerados belos adquiram um sentido cerimonial, tomem a forma de um ritual quase religioso." ${ }^{43}$ De facto o cerimonial da etiqueta e do protocolo, vão assumir na corte de Luís XIV, um verdadeiro ritual sacral e que era "religiosamente" cumprido. "Para Luís XIV, a função da etiqueta não consiste apenas em marcar a distância que o separa dos seus súbditos, a etiqueta é para ele um instrumento de dominação"44.

Versalhes não era apenas um espaço físico, mas um símbolo, a "catedral” do Rei Sol, onde se executavam as mais refinadas liturgias do Trono. Esta realidade verifica-se quando

\footnotetext{
${ }^{40}$ RIVIÈRE, Claude - As liturgias politicas. Rio de Janeiro: Imago Editora, 1989, p. 45.

${ }^{41}$ RIVIÈRE, Claude - As liturgias políticas. Rio de Janeiro: Imago Editora, 1989, p. 45.

${ }^{42}$ Memórias sobre a arte de governar. In: ELIAS, Norbert - A sociedade de corte. Lisboa: Editorial Estampa, 1987, p. 92.

${ }^{43}$ RIBEIRO, Renato Jaime - A etiqueta no Antigo Regime: do sangue à doce vida. São Paulo: editora Brasiliense, 1983, p. 23.

${ }^{44}$ ELIAS, Norbert - A sociedade de corte. Lisboa: Editorial Estampa, 1987, p. 91.
} 
mencionamos a sociedade de corte que percorria os corredores do palácio, com um objetivo bastante determinado: glorificar o seu Rei e tentar sobreviver às exigências que esta tarefa contemplava. "Hoje, o nome «Versalhes» evoca não apenas um edifício, mas um mundo social, o da corte e, especialmente, a ritualização da vida quotidiana do rei." ${ }^{25}$. O palácio era onde habitava a família real e a corte, era lá que se desenvolvia grande parte da cultura erudita e era ali, o espaço físico da mesma, o grande palco da encenação do poder absoluto.

Na construção do Estado Francês, a residência oficial do monarca e da sua corte era o ponto central para a afirmação do poder e sobretudo um poderoso instrumento para o demonstrar. $\mathrm{O}$ rei está acima de todos e é o centro, aquele que é servido pelos nobres e como tal o palácio é o lugar onde todos estes rituais se executam e se desenvolvem. A ideia deste cerimonial barroco era enfatizar o carácter divino do monarca como anteriormente referimos, a sua comparação com o sacerdote na execução do ofício da missa é perfeitamente legítima depois de uma análise das fontes que nos deixou o duque de Saint Simon.

Esta é a opinião de Luís XIV sobre a etiqueta. Para ele, não se trata de um simples cerimonial, mas de um meio de dominar os seus súbditos. O povo não crê no poder, mesmo o real, se ele não se manifesta na aparência exterior do monarca. Precisa de ver para crer. Quanto mais distante se mostra o príncipe, maior será o respeito que o povo the testemunha ${ }^{46}$.

Esta perspetiva replica o que o concílio de Trento afirmava em relação a Deus, bem como todo o cerimonial do altar como necessário para demonstrar a sobrenaturalidade. Neste sentido, o presente trabalho corrobora a leitura de Norbert Elias.

Luís XIV irá estabelecer um complexo sistema de cerimónias que irão reger todos os seus momentos públicos do acordar ao deitar:

\begin{abstract}
As ações de levantar-se pela manhã e deitar-se à noite foram transformadas nas cerimónias de lever e de coucher - com a primeira dividida em duas etapas, petit lever, menos formal e grand lever, mais formal. As refeições reais foram também ritualizadas. Luís podia comer mais formalmente (o grand couvert) ou menos formalmente (o petit couvert) mas, até mesmo as ocasiões menos formais, três petit couvert, incluíam três pratos e muitas iguarias. Essas refeições eram tomadas diante de uma audiência. Era uma honra ter permissão para assistir ao rei a comer, uma honra maior poder falar ao rei durante a refeição, uma honra suprema ser convidado a servir-lhe a comida ou a comer com ele ${ }^{47}$.
\end{abstract}

O cerimonial de corte, é para nós que estudamos os cerimoniais, comparado a título de exemplo, ao cerimonial de uma missa barroca tridentina. Tudo exala uma ordem protocolar e uma severidade de expressões físicas e situações muito próprias. Segundo as descrições de Saint Simon, as quais consultamos, o monarca começava o seu dia com a aspersão da água benta à sua pessoa, tal como se inicia uma missa tridentina.

\footnotetext{
${ }^{45}$ BURKE, Peter - A construção de Luís XIV. Casal de Cambra: Caleidoscópio, 2007, p. 97.

${ }^{46}$ ELIAS, Norbert - A sociedade de corte. Lisboa: Editorial Estampa, 1987, p. 92.

${ }^{47}$ BURKE, Peter - A construção de Luís XIV. Casal de Cambra: Caleidoscópio, 2007, p. 97.
} 
O camareiro (ou principal cavalheiro) abriu as cortinas que haviam sido fechadas novamente; e apresentou a água benta do vaso, na cabeceira da cama. No missal, por sua vez, faz-se referência à cerimónia do Aspérges no início da missa: A aspersão da água benta, que se faz aos domingos, antes das missas conventuais e paroquiais, é um sacramental...48

Antes disto o monarca já tinha sido acordado às $8 \mathrm{~h}$ da manhã ${ }^{49}$, entrando o médico da corte e as pessoas responsáveis pela sua saúde ${ }^{50}$; entretanto fechavam-se as cortinas da sua cama, no intuito de as abrir novamente para a "grande entrada".

Para a grande entrada, as cortinas do Rei eram agora abertas pelo grande cavaleiro, onde uma quantidade significativa de aristocratas e funcionários régios tinham o privilégio de assistir a pessoa do monarca a vestir-se, e a executar as primeiras orações do dia. Esta realidade acontece também na missa pontifical tridentina, onde os fiéis assistem publicamente à paramentação do bispo. ${ }^{51}$ Por ordem hierárquica as vestes reais chegavam à presença do Rei de mãos em mãos, desde o menor ao maior, tal como acontece com o bispo, onde os paramentos são trazidos pelos acólitos até chegarem às mãos do diácono e subdiácono. Só depois desta pequena procissão é que tanto o Rei como o bispo são ornamentados com as suas vestes próprias. No caso da missa as orações ao pé do altar são outro exemplo desta mesma semelhança. ${ }^{52}$

Quem abriu as cortinas e apresentou a água benta, apresentou também um livro de orações. Então todos passaram para o gabinete do conselho. Terminando um culto religioso muito curto, o rei chamou e eles entraram novamente. O mesmo oficial the deu o seu roupão; imediatamente depois, outros cortesãos privilegiados entraram... ${ }^{53}$

De seguida, o Rei Sol volta a orar a Deus no seu quarto, na presença de numerosos clérigos que com ele se ajoelham. Entretanto aparece o capitão da guarda real e encaminha o rei, com numeroso aparato de cortesãos e clérigos, para o seu gabinete ${ }^{54}$, qual expressividade de gestos barrocos e de profusos salamaleques. Poderíamos comparar esta cerimónia com o Introito da Missa até à leitura do Evangelho, com o intuito de oração pública. O Rei parece desenvolver uma cerimónia idêntica, no sentido de estabelecer vários momentos de oração até chegar ao seu gabinete ${ }^{55}$.

\footnotetext{
${ }^{48}$ LEFEBVRE, Gaspar - Missal Romano Quotidiano. Santo Tirso: Mosteiro de Singeverga, 1963, p. 735.

49 “Às oito horas, o valete de câmara, que sozinho dormira na câmara real e se vestia, acordou o rei." (SAINT-SIMON, Louis De Rouvroy, Duc de - Mémoires sur le règne de Louis XIV et la Régence. Paris: Librairie Larousse.)

50 "O médico chefe, o cirurgião chefe e a enfermeira...entraram ao mesmo tempo" (SAINT-SIMON, Louis De Rouvroy, Duc de - Mémoires sur le règne de Louis XIV et la Régence. Paris: Librairie Larousse.)

51 "Pro Missa solemni pontificali ab Episcopo celebranda, decet ut sacellum deputetur in Ecclesia, ubi non adsit secretarium, ad sacra indumenta accipienda." (IGREJA CATÓLICA - Caeremoniale Episcoporum ex decreto Sacrosancti Concilii Tridentini. Roma: Editio Novissima Juxta Typicam).

${ }^{52}$ Ad Missa, "Orações ao Pé do Altar" [Sinal da Cruz, Salmo 42, Confissão, Confissão do acólito em nome do povo, Subida ao altar do Sacerdote]. (IGREJA CATÓLICA - Missale Romanum ex decreto Sacrosancti Concilii Tridentini. Tours: Sumptibus et typis Mame (Sacrae Rituum Congregationis Typographorum), 1957).

${ }^{53}$ SAINT-SIMON, Louis De Rouvroy, Duc de-Mémoires sur le règne de Louis XIV et la Régence: extraits. Paris: Librairie Larousse. 54 “Assim que se vestiu, orou a Deus, ao lado de sua cama, onde todos os clérigos presentes estavam ajoelhados, os cardeais sem almofadas, todos os leigos permanecendo de pé; e o capitão dos guardas chegou à balaustrada durante a oração, após a qual o rei entrou no seu gabinete." (SAINT-SIMON, Louis De Rouvroy, Duc de Mémoires sur le règne de Louis XIV et la Régence. Paris: Librairie Larousse)

${ }^{55}$ Ver as folhas de cálculo em formato Excel disponíveis em anexo, onde comparamos os dois ritos.
} 
Depois de haver-se instalado no gabinete, Luís XIV dá uma série de ordens aos seus ministros com as tarefas que devem executar durante o dia. Nas primeiras horas da manhã trata de assuntos de Estado e trabalha no que lhe apraz e é mais necessário, ou então concede audiências aos interessados. Antes do almoço, acontece o ponto culminante do seu dia, que é a assistência ao ofício da Missa. Sabemos, segundo Saint Simon, que esta era sempre cantada pelos seus músicos ${ }^{56}$.

Saint Simon, que é conhecido por não poupar críticas ao Rei nos seus escritos, insuspeitamente relata-nos um monarca de grande piedade e devoção pela religião. Entre outras coisas, sabemos que Luís XIV proibia, no período da Quaresma, sob castigo, a quem no palácio comesse carne.

Durante toda a sua vida, o rei falhou apenas uma vez na sua participação da missa. Foi com o exército, durante uma marcha forçada; ele não perdeu nenhum dia, a menos que estivesse realmente indisposto. Alguns dias antes da Quaresma, ele declarou publicamente que ficaria muito descontente se alguém comesse carne ou a desse a outros, sob qualquer pretexto... Na igreja, ele era muito respeitoso. Durante a sua missa, todos foram obrigados a ajoelharse e a permanecer assim até depois da comunhão do sacerdote; e se ouvia o mínimo barulho ou via alguém a falar durante a missa, ficava muito descontente. Ele tomava a comunhão cinco vezes por ano... ${ }^{57}$

Depois da missa, é no almoço que se dá o grande aparato de assistência, é aqui que inclusivamente os diplomatas que visitavam o palácio assistiam ao banquete da Majestade Cristianíssima. Eram acontecimentos inauditos segundo os relatos, uma instituição exclusiva do Rei Sol, onde predominava um intenso culto à instituição monárquica através da sua pessoa. Como de um ritual religioso se tratasse, havia um profundo silêncio e respeito pela sacralidade régia que se dignava aparecer aos olhos dos seus cortesãos, qual imitação da última ceia de Cristo com os seus apóstolos. Poder ver o Rei de França a almoçar era um privilégio de poucos e inclusiva-mente uma mercê de grande honra e distinção. Naquela sala não estava Luís, estava o lugar-tenente de Deus na terra, um ministro sagrado, pontífice entre o mundo terreno e o sobrenatural ${ }^{58}$.

O ritual, como vimos, era algo habitual na corte do Rei Sol. A comparação que fazemos com os ritos eclesiásticos tem a finalidade de fazer entender ao leitor uma crença particular de que todo este cerimonial tem como fonte as expressões litúrgicas da Igreja. Acreditamos que

\footnotetext{
56 "O rei foi à missa, onde os seus músicos sempre cantaram um hino. Ele não foi para baixo, exceto em festas ou em cerimónias." (SAINT-SIMON, Louis De Rouvroy, Duc de - Mémoires sur le règne de Louis XIV et la Régence. Paris: Librairie Larousse).

${ }^{57}$ SAINT-SIMON, Louis de Rouvroy, Duc de - Mémoires sur le règne de Louis XIV et la Régence. Paris: Librairie Larousse. 58 "O número de pessoas que podiam assistir ao almoço era muito limitado. Mesmo um posto militar muito alto não era suficiente. M. de Vauban, ficou impressionado com a distinção (...) Todos os clérigos foram excluídos, exceto os cardeais e os bispos, padres ou eclesiásticos que mantinham o posto de príncipes estrangeiros (...) Nessas refeições, todos estavam cobertos; seria uma falta de respeito, da qual a pessoa em questão seria imediatamente informada, se não tivesse mantido o chapéu na cabeça. Somente o rei tinha a cabeça descoberta. Quando o rei queria falar com alguém, ou alguém tinha a oportunidade de lhe falar, tinha então de descobrir a cabeça (...) Só o rei tinha uma poltrona. Todos os outros convidados, inclusive o Delfim, tinham assentos com costas de couro preto de Marrocos, que podiam ser dobradas para serem transportadas (...) exceto no exército, o rei nunca comeu com ninguém, sob quaisquer circunstâncias; nem mesmo com os príncipes do sangue." (SAINT-SIMON, Louis De Rouvroy, Duc de - Mémoires sur le règne de Louis XIV et la Régence. Paris: Librairie Larousse).
} 
esta influência explica a sustentação do Estado Absoluto e que a aliança entre o Trono e o Altar foi fundamental para a sua manutenção no caso francês. "Poder-se-ia estender esta abordagem, razoavelmente, à restante vida quotidiana do rei - a missa diária dele, as reuniões com os seus conselheiros, e até mesmo as suas campanhas, as suas expedições de caça e os seus passeios á volta dos seus jardins" $" 59$.

A verdade é que todas estas cerimónias, como vimos, desde o acordar ao deitar do monarca, são minuciosamente regidas por ritos previamente desenhados e detalhadamente executados.

Pode-se pensar que ampliar a análise deste modo é diluir o termo "ritual", até que este perca a maior parte do seu significado. Contudo, os observadores registaram que todas as ações do rei foram planeadas, "até o gesto mais insignificante". Os mesmos factos ocorriam diariamente à mesma hora, de tal modo que se podia ajustar o relógio pelo rei ${ }^{60}$.

Convém destacar que, neste espaço social, o monarca está no centro, como na Missa, Cristo o ocupa. A aristocracia regia-se em torno do rei, e era aqui o palco social onde se obtinham privilégios e se fazia distinguir cada um por uma rigorosa hierarquia:

Muito importante, embora limitado à aristocracia, era o ritual de corte, particularmente o da câmara do rei, que servia para estabelecer as diferenças de hierarquia para distribuir distinções e favores, ou, pelo contrário, expressar o desagrado. Na suas Memórias, Luís XIV realçava o papel político desempenhado pela etiqueta: "Enganam-se redondamente aqueles que julgam que é apenas uma questão de cerimónia. Os povos sobre os quais reinamos, não podendo penetrar no fundo das coisas, orientam normalmente os seus juízos pelo que vêm por fora, e a maior parte das vezes é pela hierarquia e pela classe social que medem o seu respeito e obediência" ${ }^{\prime \prime}$.

O cerimonial e o protocolo eram uma forma de tornar visível o poder e também uma forma de educação moral. Era, portanto, o molde social da corte, as rúbricas pelas quais se regiam os cortesãos, como o padre a Deus as preces numa Missa.

Havia regras formais para a participação neste espetáculo - a quem era permitido observar o rei, a que horas e em que zonas da corte, se tal pessoa podia sentar-se numa cadeira ou num tamborete ou permanecer de pé. A vida quotidiana do rei foi composta por ações que não eram tão somente repetitivas, mas carregadas de significado simbólico porque eram desempenhadas em público por um ator, cuja pessoa era sagrada ${ }^{62}$.

Em continuidade com o que dizíamos atrás, o rei era comparado quase a um santo e simplesmente o facto de tocar em objetos os transformava em relíquias sagradas. Aqui se verifica uma vez mais a osmose entre poder temporal e religioso, por outro lado, gestos reverenciais como genuflexões que eram utilizados pela Igreja para o culto a Deus, eram também utilizados pela corte de Versalhes para reverenciar o monarca.

Os objetos materiais intimamente ligados ao rei tornaram-se por sua vez, sagrados, porque o representavam. Consequentemente, era uma ofensa voltar as costas ao retrato do rei, entrar

\footnotetext{
${ }^{59}$ BURKE, Peter - A construção de Luís XIV. Casal de Cambra: Caleidoscópio, 2007, p. 99.

${ }^{60}$ BURKE, Peter - A construção de Luís XIV. Casal de Cambra: Caleidoscópio, 2007, p. 99.

${ }^{61}$ BONNEY, Richard - O Absolutismo. Mem Martins: Publicações Europa América, 1989, p. 47.

${ }^{62}$ BURKE, Peter - A construção de Luís XIV. Casal de Cambra: Caleidoscópio, 2007, p. 100.
} 
no seu dormitório vazio sem fazer uma genuflexão, ou usar chapéu na sala onde a mesa estivesse posta para o jantar do rei $^{63}$.

Neste sentido, o monarca era em tudo uma figura pública, que não vivia para si mesmo, mas para os seus súbditos. Assim ensinava o próprio aos restantes membros da família real: “«Nós não somos os particulares. Pertencemos inteiramente ao público.» Com estas palavras, dirigida ao delfim, Luís XIV sublinhava a obrigação que o rei tinha de «manter a sua corte»"64.

No que respeita a uma análise mais pormenorizada dos ritos e das suas origens sabemos que estes possivelmente já existiam antes de Luís assumir o poder. Todavia, comparamos o Rei Sol ao próprio Concílio de Trento, que de alguma maneira veio embelezar e dar notoriedade a esses ritos.

Como o sociólogo Norbert Elias salientou, num argumento paralelo a Marc Bloch sobre o toque real, estes rituais não devem ser dispensados como meras curiosidades. Devem ser analisados pelo que nos podem contar sobre a cultura circundante - sobre a monarquia absoluta, a hierarquia social, e assim por diante ${ }^{65}$.

Ainda outro aspeto que gostaríamos de sublinhar, é o facto de todas estas cerimónias e regras de comportamento, para além daquilo que foi mencionado anteriormente, terem uma função significativa de distinguir a cultura popular ${ }^{66}$ da cultura erudita da aristocracia. "Sejam quais forem as cerimónias que se recordem, em todas elas a sociedade de corte procura distinguir entre comportamentos civilizados e comportamentos «populares»" ${ }^{" 67}$. O cerimonial, muito mais que um conjunto de regras, era uma forma de vida e de arte. Tal como nas rúbricas religiosas se passa do papel aos ritos, a corte era a executante que dava vida aos cerimoniais de etiqueta, tendo o Rei por principal protagonista.

\subsubsection{A coroação e a cerimónia da sagração.}

É na cerimónia da coroação que podemos estabelecer melhor a comparação entre os ritos temporais e religiosos; é aqui que temos indiscutivelmente a relação perfeita entre o Trono e o Altar. Se olharmos para a sagração dos bispos vamos encontrar elementos comuns: seja na invocação das ladainhas, na unção, na entrega das insígnias, seja na própria coroação do Rei, ou na imposição da mitra ao bispo. Contudo, a coroação não deixa de ser um rito religioso, o que demonstra precisamente a supremacia do poder espiritual sobre o temporal. O próprio Luís

\footnotetext{
${ }^{63}$ BURKE, Peter - A construção de Luís XIV. Casal de Cambra: Caleidoscópio, 2007, p. 100.

${ }^{64}$ BONNEY, Richard - O Absolutismo. Mem Martins: Publicações Europa América, 1989, p. 47.

${ }^{65}$ BURKE, Peter - A construção de Luís XIV. Casal de Cambra: Caleidoscópio, 2007, p. 99.

66 "Encontramos aqui uma constante. Nos processos judiciários ou nos almanaques, na literatura de cordel ou na parenética, a distinção entre civilização e popular torna-se recorrente, ao mesmo tempo que se procura implantar nos grupos sociais inferiores as novas normas de comportamento, as transformações de hábitos sociais promovidas pela sociedade de corte." (SOUSA, Ivo Carneiro de - História de Portugal moderno: economia e sociedade. Lisboa: Universidade Aberta, 1996, p. 260).

${ }^{67}$ SOUSA, Ivo Carneiro de - História de Portugal Moderno. Lisboa: Universidade Aberta, 1996, p. 260.
} 
XIV não foi exceção, ele mesmo se submeteu a este ritual, e certamente não o poderia dispensar para a afirmação do seu poder.

Esta cerimónia era uma das mais importantes e únicas em toda a vida do monarca. Ela acontecia algum tempo depois da morte do último rei e tendo terminado o tempo de luto, iniciava-se assim os ritos consecratórios com os óleos sagrados, que no caso francês, apareceram supostamente milagrosamente no tempo de São Remígio. "Na manhã da cerimónia, quatro senhores da mais antiga nobreza são enviados em cortejo para buscar na Abadia de Saint Remis a santa ampola de óleo perfumado que teria sido trazida por uma pomba quando do batismo de Clóvis, no Natal de 498"68.

A cerimónia realizava-se em latim e sobressaíam aqui os dois juramentos, à Igreja e ao Reino, que eram, também eles, pronunciados em latim. "Em tempos normais, a coroação verificavase pouco depois da subida ao trono do novo rei, e o rei de França prestava dois juramentos em latim, um dirigido aos bispos e à Igreja, o outro o «juramento do reino» propriamente dito" ${ }^{69}$. Notese que o primeiro juramento era dirigido em primeiramente à Igreja. Nada era por acaso no cerimonial, e mesmo aqui sobressaía a questão hierárquica, onde o poder espiritual se sobrepunha ao pode temporal. Ainda que esta premissa nos pareça medieval, o reinado de Luís XIV e o Antigo Regime Francês nunca perdeu, ao contrário de certas concessões historiográficas, no nosso entender erradas, esta hierarquia de valores.
A sagração é ao mesmo tempo um fator de fortalecimento da autoridade monárquica, através do reconhecimento de uma legitimidade hereditária, simbolicamente eletiva ("Viva o Rei"), e um rito indicativo da limitação dessa autoridade, pois a Igreja, conferindo e abençoando o cetro e o gládio, enuncia com isso a supremacia do poder espiritual sobre o temporal ${ }^{70}$.

No rito de sagração episcopal estes juramentos também aconteciam, neste caso proferidos pelos eleitos ao episcopado ${ }^{71}$. Mais tarde começavam as ladainhas ${ }^{72}$, tal como na coroação, pedindo a todos os santos os auxílios para o exercício do ministério sagrado. De seguida aconteciam as unções com os santos óleos, momento alto destas cerimónias, tal como no Antigo Testamento eram ungidos Sacerdotes, Reis e Profetas ${ }^{73}$. Seguia-se no caso dos Reis

\footnotetext{
${ }^{68}$ RIVIÈRE, Claude - As liturgias politicas. Rio de Janeiro: Imago Editora, 1989, p. 47.

${ }^{69}$ BONNEY, Richard - O Absolutismo. Mem Martins: Publicações Europa América, 1989, p. 50.

${ }^{70}$ RIVIÈRE, Claude - As liturgias políticas... p. 48.

71 "Ego N. Eléctus Ecclésiæ N. ab hac hora in ántea fidélis, et obédiens ero beáto Petro Apóstolo, sanctæque Románæ Ecclésiæ et Dómino nostro, Dómino N. Papæ N. suísque Successóribus canónice intrántibus.” [E, eleito da Igreja, nesta hora como fiel e obediente servo ao Beato Pedro apóstolo, à Santa Igreja Romana e a nosso senhor o Papa aos seus sucessores canónicos...] (IGREJA CATÓLICA -Pontificale Romanum ex decreto Sacrosancti Concilii Tridentini).

72 «Consecrator incipit Litanias, dicens: Kýrie, eléison, etc,» [O bispo consagrante começa as ladainhas...] (IGREJA CATÓLICA - Pontificale Romanum ex decreto Sacrosancti Concilii Tridentini); e ainda no rito de coroação: "Tunc cantores incipiunt, et prosequuntur Litanias." [E os cantores iniciam e prosseguem com as ladainhas] (IGREJA CATÓLICA - Pontificale Romanum ex decreto Sacrosancti Concilii Tridentini).

73 "Ali, Zadoque, o sacerdote, e Natã, o profeta, deverão ungi-lo rei sobre Israel. Tocarão a trombeta e gritarão: Viva o rei Salomão!". (1 Rs 1, 34.)
} 
a coroação, que no caso francês havia certa particularidade, para além das normas contidas no pontifical Romano.

Na coroação, o rei recebe duas coroas: a primeira, mais pesada, conhecida como sendo a de Carlos Magno, é colocada pelo arcebispo sobre a cabeça do rei e sustentada pelos doze pares do reino. Em seguida, ela é substituída por uma segunda mais leve que o rei mantém até ao final da cerimónia. Por fim, já fora da catedral, o rei usava uma terceira coroa, feita especialmente para ele $\mathrm{e}^{74}$

Na cerimónia de sagração apresentava-se uma constituição hierárquica das personagens que compunham as elites da época. Mesmo o clero durante o rito usava de ornamentos distintos para vincar o seu lugar na hierarquia. O celebrante portava as insígnias episcopais mais importantes e os que tinham o título cardinalício, ou bispos autorizados, apareciam com compridas capas magnas de seda, cobertas de pele de arminho. As alfaias litúrgicas eram riquíssimas, desde os bordados a ouro, passando pelos objetos sacros que compunham o tesouro da catedral de Reims.

Outra grande evidência da penetração régia no poder religioso e vice-versa é sobretudo o particularismo da Sagração francesa com relação ao ritual do Pontificale Romanum. Aqui destacaríamos as funções de clérigo, que o próprio Rei executava durante a grande missa celebrada pelo arcebispo de Paris na Coroação. Apresentamos deste modo as descrições deste momento ritual:

Depois o Arcebispo celebra a grande missa... após o canto do evangelho, o missal do altarmor é dado ao rei para ser beijado. Este, no ofertório, entregará ao arcebispo o vinho, o pão de ouro, o pão de prata e uma bolsa. O beijo da paz é dado ao rei pelo bispo que faz as vezes do diácono. A comunhão do monarca ocorre sob as duas espécies ${ }^{75}$.

Voltando aos juramentos, o grande teórico do absolutismo e mentor de Luís XIV, Jaques Bossuet, diz-nos na descrição da cerimónia o seguinte:

O príncipe jura a Deus na sua sagração...manter os privilégios das Igrejas; conservar a Fé católica que recebeu dos seus pais; impedir violências e prestar justiça a todos os seus súbditos. Este juramento é o fundamento da tranquilidade pública: e Deus é tanto mais obrigado a fazê-lo respeitar pela sua própria verdade quanto é Ele o único vingador ${ }^{76}$.

Esta descrição a exortar às obrigações régias está patente e de forma explícita no próprio juramento presente no Cérémonial français editado por Théodore e Denis Godefroy em 1649 que o traduziram do latim para o francês: "Prometo conservar-vos, e às vossas Igrejas, o privilégio canónico, com a lei e a justiça que lhe são devidas. E prometo conceder-vos a defesa destas coisas, como é dever de um rei concedê-la por direito no seu reino a um bispo e à Igreja que lhe está confiada"77.

\footnotetext{
${ }^{74}$ DOMINGUES, Joelza Ester - Retrato de Luís XIV: ícone do absolutismo monárquico - Ensinar História. [Em linha]. s. num..

${ }^{75}$ RIVIÈRE, Claude - As liturgias políticas. Rio de Janeiro: Imago Editora, 1989, p. 48.

${ }^{76}$ BONNEY, Richard - O absolutismo. Mem Martis: Publicações Europa América, 1989, p. 50.

${ }^{77}$ BONNEY, Richard - O absolutismo. Mem Martis: Publicações Europa América, 1989, p. 50.
} 
$\mathrm{Na}$ segunda promessa do monarca estava patente a sua função de defensor da Fé em nome de Cristo ao seu povo:

Prometo, em nome de Jesus Cristo, estas três coisas ao povo cristão que me está entregue. Em primeiro lugar, que todo cristão da Igreja de Deus conserve todo o tempo, sob as nossas ordens a paz verdadeira. Em segundo lugar, que eu proíba toda a rapacidade e iniquidade. Em terceiro lugar, que em todos os julgamentos eu ordene a equidade e a misericórdia ${ }^{78}$.

Por outro lado, os juramentos estavam fortemente assentes na força e no vigor da tradição monárquica. O rei não é um inovador, mas um garante da gloriosa tradição e das tradições que herdou dos seus pais:

O rei comprometia-se a "governar e a defender" o reino que Deus lhe confiara "segundo a justiça dos [seus] pais". Além disso, prometia "defender as santas Igrejas de Deus e os seus pastores e todo o povo que lhes está submetido, com justiça e com religião, por uma real providência, segundo os costumes dos seus pais." Finalmente, comprometia-se por juramento a: "conservar a soberania, os direitos e nobrezas da coroa de França: sem os alienar ou entregar a ninguém, e exterminar de boa-fé, segundo o seu poder, todos os heréticos apontados e condenados pela Igreja ${ }^{79}$.

Todas estas consignações podem-se, facilmente, resumir num pequeno parágrafo escrito por Bossuet: "Primeiramente, a autoridade real é sagrada. Em segundo lugar, é paternal. Em terceiro lugar, é absoluta, o que quer dizer independente. Em quarto lugar, está submetida à razão"80. Estava assim consagrado o Estado Absoluto assente na tradição dos Antigos, sendo estes ritos sacrais mais do que outorgantes de poder: eram seus testemunhas. $\mathrm{O}$ famoso retrato de Rigaud demonstra iconograficamente os símbolos do poder sacral régio, e por isso merce da nossa parte uma breve análise.

“A boca está fechada, irónica e determinada, os olhos têm um brilho duro e escuro, o nariz fino revela intransigência. Este monarca não é bom nem mau, mas está além de todas as categorias morais" $"$. Este, se quisermos, é um dos melhores resumos daquilo que pretendia Rigaud ao representar o monarca. A pintura de Luís XIV, o Rei Sol, em trajes de coroação, é muito mais do que um retrato do Rei. Ela está repleta de símbolos e de elementos decorativos, intencionalmente inseridos pelo pintor para exaltar o poder e a soberania real e reforçar a sacralidade do monarca absoluto. Mais do que um "retrato oficial" de Luís XIV, este quadro é a representação iconográfica do Absolutismo de origem divina por excelência. Quase que se poderia ouvir através dele, a célebre frase: “O Estado Sou Eu.”. E de facto o retrato representa o Estado, daí a importância do resumo de Andreas Prater, ao afirmar que Luís XIV está por cima das categorias morais. Este retrato tão amado pelo próprio monarca pretendeu ser na época uma representação fiel e materializada da força e da grandeza de França, o proselitismo baluarte

\footnotetext{
${ }^{78}$ BONNEY, Richard - O absolutismo. Mem Martis: Publicações Europa América, 1989, pp. 50-51.

${ }^{79}$ BONNEY, Richard - O absolutismo. Mem Martis: Publicações Europa América, 1989, p. 51.

${ }^{80}$ BONNEY, Richard - O absolutismo. Mem Martis: Publicações Europa América, 1989, p. 51.

${ }^{81}$ PRATER, Andreas - A pintura do Barroco. Lisboa: Taschen, 1997, p. 55.
} 
da Fé, a consequência inevitável da grande "era tridentina"! Nem no tempo dos "Augustos" Romanos a Europa, (o mundo), pode vislumbrar semelhante glória como a que o Rei Sol queria transmitir. Este é sem sombras de dúvidas um exemplo da arte e dos movimentos culturais ao serviço do poder.

O retrato em si impera pelas suas grandes dimensões: 2,77 metros de altura e 1,94 m. de largura. A ideia era tornar o monarca maior do que a sua altura verdadeira. Luís XIV olha, portanto, por cima do espectador com um ar de superioridade. A sua posição está inclinada para a esquerda, quase que torcida para enfatizar uma leve ideia de movimento tipicamente barroca herdada já do tempo maneirista italiano. A mão direita segura o cetro e a esquerda repousa na cintura. "O retrato de Luís XIV prima pelo luxo do cenário e pela riqueza do vestuário e dos acessórios refletindo a glória e a pompa da corte do Rei Sol, em Versalhes" ${ }^{\text {}}$. Para além da ornamentação barroca que o quadro encerra, ela é também uma alegoria muito clara aos Imperadores Romanos através de uma simbologia concreta e sobretudo a utilização de elementos pictóricos da época:

O rei está sobre um tablado tendo acima da sua cabeça, um enorme dossel de seda vermelha ou púrpura (a cor usada pelos césares desde a Antiguidade), com frisos, cordões e pingentes dourados. A seus pés, um magnífico tapete de seda bordado onde predomina o dourado. $\mathrm{O}$ conjunto formado pelo dossel e plataforma lembra, também, um palco teatral com as suas pesadas cortinas - efeito que evoca a representação do poder real. Ao fundo, atrás do rei, está o trono do qual só vemos o espaldar alto e parte do braço esquerdo. O lugar da autoridade que marca o centro do poder e do reino parece escondido, eclipsado pela figura central e luminosa do rei. Uma posição bem simbólica, afinal Luís XIV é a encarnação do Estado como sintetiza a célebre frase L'Etat c'est moi (“O Estado sou eu”) atribuída a ele ${ }^{83}$.

Por fim, podemos observar mais um pormenor de alusão ao mundo Antigo, ainda que de forma discreta: "Um grande pilar de mármore reforça a composição vertical do quadro que tem como eixo central a figura de Luís XIV. A base do pilar tem figuras esculpidas nos dois lados visíveis que simbolizam virtudes reais: a alegoria da Justiça (de frente) e a da Força (à esquerda) ${ }^{\prime 84}$.

\footnotetext{
${ }^{82}$ DOMINGUES, Joelza Ester - Retrato de Luís XIV, 24 Mar. 2015. [Em linha]. s. num..

${ }^{83}$ DOMINGUES, Joelza Ester - Retrato de Luís XIV, 24 Mar. 2015. [Em linha]. s. num..

${ }^{84}$ DOMINGUES, Joelza Ester - Retrato de Luís XIV, 24 Mar. 2015. [Em linha]. s. num..
} 
Fig. 3 - Hyacinthe Rigaud - "Luís XIV, Rei de França”, (1638-1715)

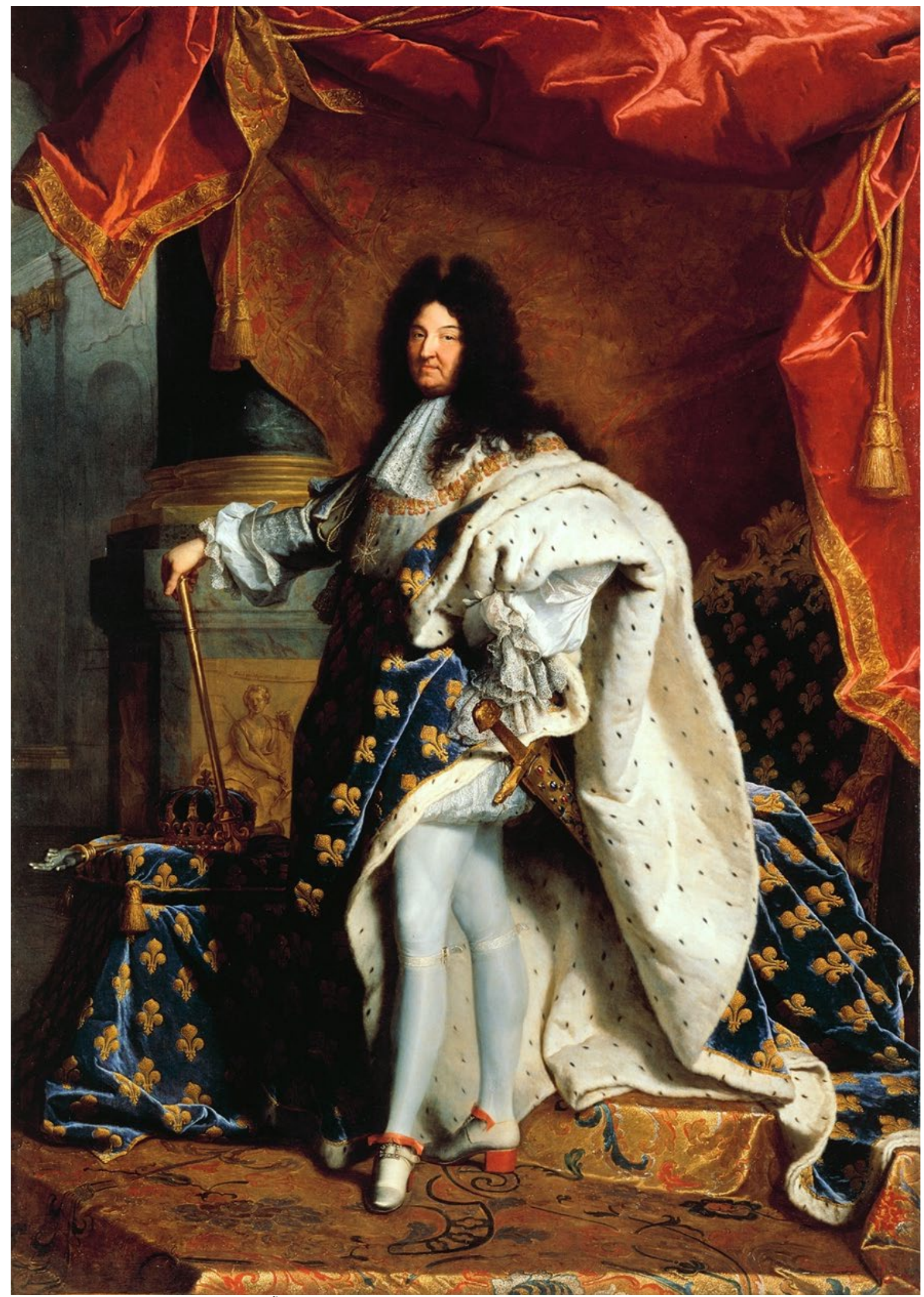

DESCRIÇÃO: óleo sobre tela, 277 x 194 cm. FONTE: Musée du Louvre, Paris. 


\title{
3. A influência tridentina e a sacralidade régia
}

Na compreensão desta questão começamos por esclarecer que Luís XIV era considerado pela tradição, tal como os seus antecessores, um monarca taumaturgo. No retrato de Jean Jouvenet, que de seguida apresentamos, vemos o Rei Sol a curar um enfermo com o seu toque. A ideia que fica desta cerimónia é o carácter sacerdotal do monarca. Desde tempos ancestrais esta posição do sacerdócio real é transmitida através dos ritos sacrais católicos. O rito de sagração do rei conferia, segundo a época, poderes especiais ao monarca e um deles era o de curar enfermos. Tocar no Rei era sacrilégio, ser tocado pelo rei era ser tocado pelo próprio Deus! O toque real é uma forma de imposição das mãos que tem origens medievais com os reis taumaturgos entre eles os monarcas Ingleses, como por exemplo São Eduardo, o Confessor ${ }^{85}$. Inclusivamente os próprios reis do Reino Unido, são sagrados no trono de São Eduardo. Segundo Marc Bloch: "Julgava-se que esses reis eram verdadeiramente divinos e possuíam certo poder sobre a natureza" ${ }^{\sharp 6}$.

Apesar de toda esta ênfase na sacralidade do rei, não se pode afirmar em absoluto que este se considerava um deus, à semelhança de autocracias como as que vigoraram no Egipto. Pelo contrário, Luís Augusto era "o servo de Deus na terra" e recebia dele a potestade para bem governar o seu reino. Apesar de algumas tensões com a Santa Sé, o monarca sempre se manteve unido à religião Católica de quem segundo a Tradição era também ele herdeiro espiritual.

Esta dimensão é importante à história da cultura, pois irá levar à realização massiva de obras de arte com o intuito de representar o monarca como defensor da fé.

\begin{abstract}
As representações oficiais da Revogação incluíram também medalhas, que sustentavam inscrições concebidas pela petit academie, tais como "a verdadeira religião vitoriosa" [RELIGIO VICTRIX], "a heresia extinta" [EXTINCTA HAERESIS], "os templos calvinistas destruídos" [TEMPLIS CALVINIANORUM EVERSIS] ou "Dois milhões de Calvinistas devolvidos à Igreja" [VICIES CENTENA MILLIA CALVINIANORUM AD ECCLESIAM REVOCATA]. A estátua de Luís de Desjardins, na Place des Victoires incluem baixo-relevo da Revogação. A Academia Real de pintura escolheu "o triunfo da Igreja" e a "heresia esmagada sob os pés", como temas para ilustrações de diplomas...Philippe Quinault terminou uma carreira de vinte anos como libertista para bailados e óperas da corte, com uma epopeia intitulada $L$ 'hérésie détruit, enquanto Charles Perrault escreveu uma ode para os "recém-convertidos", felicitando-os juntamente com o seu monarca "magnânimo" "87.
\end{abstract}

\footnotetext{
85 "Os reis da França e da Inglaterra puderam tornar-se médicos milagrosos porque já eram, havia muito tempo, personagens sagradas: «sanctus enim et christus Domini est» ["o rei é santo; é o ungido do Senhor"], dizia Pierre de Blois, a fim de justificar as virtudes taumatúrgicas de seu monarca, Henrique II" (BLOCH, Marc-Os Reis Taumaturgos o caráter sobrenatural do poder régio França e Inglaterra. São Paulo: Companhia das letras, 1999, p. 70).

${ }^{86} \mathrm{BLOCH}$, Marc - Os Reis Taumaturgos. O caráter sobrenatural do poder régio França e Inglaterra. São Paulo: Companhia das letras, 1999, p. 71.

${ }^{87}$ BURKE, Peter - A construção de Luís XIV. Casal de Cambra: Caleidoscópio, 2007, p. 112.
} 
Todas estas representações e alegorias devem levar-nos a perceber o catolicismo como forma de promover a sumptuosidade através de ritos marcantes, que o monarca usaria tanto para agradar a Deus, como para enaltecer a sua figura.

Antes de abordarmos a questão do édito de Nantes, importa assegurar a importância da reforma tridentina nesta questão. A arte da Reforma, o barroco, e todo o seu cerimonial são, no nosso entender, meios eficazes de persuasão para intimidar os protestantes e todos aqueles que se rendiam ao esplendor da "verdadeira religião" e adensadas pela arte sacral do exagero e da opulência, as faustosas procissões em honra dos santos, as cerimónias presididas pelo alto clero até às alfaias compridas e vistosas como as capas magnas usadas pelos bispos e cardeais, faziam parte da exibição do poder que o Rei Sol soube manipular, também para seu benefício próprio e que o mundo protestante criticava. É neste sentido que Luís XIV se irá destacar aquando da aplicação do proselitismo tridentino com a revogação do édito de Nantes, numa resposta firme do Estado Absoluto com uma só Fé, da qual ele era o defensor.

Só se pode entender esta medida, no sentido de que Luís XIV acreditava piamente na sua religião, pois a revogação do édito e a expulsão dos protestantes, levaria a consequências negativais para a França a nível económico. “A decisão do rei de proibir o protestantismo (...) levou à emigração de aproximadamente 200.000 homens e mulheres francesas" ${ }^{\$ 9}$. O clero e a nobreza puritana, através de rasgados elogios, souberam convencer o rei a continuar a sua missão de expurgar a heresia e render todos os louvores à religião Católica.

O elogio mais famoso do rei para essa acção especial, foi um sermão de Bossuet pregado no funeral do antigo ministro Michel Le Tellier, e que descreve Luís como "este novo Teodósio, este novo Marcion, este Novo Carlos Magno". Os jesuítas, particularmente, trabalharam este tema. Philibert Quartier, professor no colégio jesuíta em Paris, recém-nomeado Louis-Le-Grand, emitiu um panegírico sobre o rei "por ter extinguido a heresia" [pro extincta haeresi] ${ }^{90}$.

O Édito de Nantes foi em si um instrumento poderoso e uma conquista da Igreja, especialmente dos jesuítas que anteriormente instigavam esta ação do monarca:

Com retrospeção, os bailados e orações anteriores podem ser interpretados como encorajamento jesuíta da campanha antiprotestante, como por exemplo, Constantine: le trionphe de la religion (apresentado em 1681, ano em que Estrasburgo regressou forçosamente ao catolicismo), e Ludovicus Pius ${ }^{91}$.

\footnotetext{
${ }^{88}$ Esta crença da Igreja de reivindicar para si a sua fundação como divina e por isso a única verdadeira.

${ }^{89}$ BURKE, Peter - A construção de Luís XIV. Casal de Cambra: Caleidoscópio, 2007, p. 108.

${ }^{90}$ BURKE, Peter - A construção de Luís XIV. Casal de Cambra: Caleidoscópio, 2007, p. 114.

${ }^{91}$ BURKE, Peter - A construção de Luís XIV. Casal de Cambra: Caleidoscópio, 2007, pp. 114-115.
} 
Fig. 4 - Jean Jouvenet - “O toque real das escrófulas". “O rei te toca, Deus te cure", (1690) [pormenor]

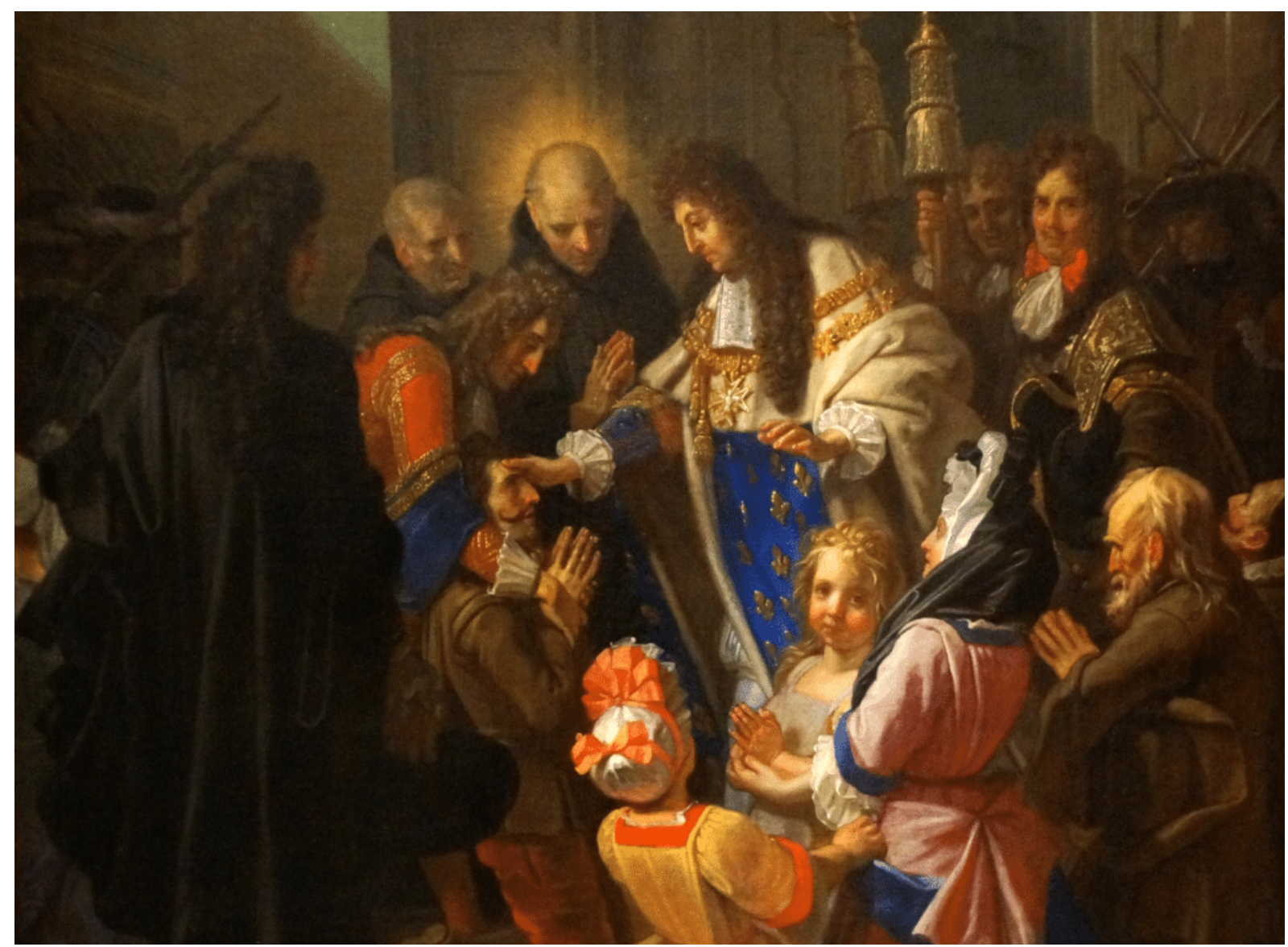

DESCRIÇÃO: óleo sobre tela. FONTE: Abadia de Saint-Riquier, França.

\section{Conclusão}

Depois de uma significativa leitura bibliográfica e de uma intensa reflexão das fontes que nos propusemos estudar, podemos retomar a questão \problema colocados no início desta investigação. A influência de uma cultura Católica assente no ritual e na cerimónia teve com toda a certeza uma grande influência na construção de um cerimonial de Trono. Contudo, não podemos deixar de alertar que esta realidade estudada prende-se totalmente com o caso francês, pelo que seria interessante verificar esta mesma circunstância noutros casos concretos e até mesmo fora do espaço europeu. De qualquer forma, fica evidenciada a importância do poder espiritual na edificação do Absolutismo de direito divino, sendo que sabemos de antemão a importância francesa como influenciadora de outros modelos políticos deste período, incluindo Portugal.

Fora da nossa análise ficou a questão do designado "despotismo iluminado" que surgirá em finais de seiscentos e permanecerá ao longo de setecentos. No nosso entender, não há uma relação direta entre a afirmação do poder régio e a emergência de um Estado autocrático assente unicamente no poder temporal, como iremos verificar no período pós 1789. Como demonstrado, e as fontes são inequívocas, o período pré revoluções, ou seja, o designado Antigo 
Regime, estava fortemente sustentado pela crença religiosa, e era através da religião que os monarcas como Luís XIV iriam buscar a sua legitimidade de ação. Em nenhum momento se verificou no longo reinado do Rei Sol uma tentativa de apartar a religião ou submetê-la a um papel secundário, como sustentaram algumas correntes historiográficas das quais nos posicionamos abertamente contra.

Daquilo que nos foi possível abordar no que respeita à documentação, ficamos com uma perspetiva do muito que ainda falta estudar sobre estas matérias, no intuito de compreender melhor a sociedade de corte deste período. A própria aristocracia e a sua ação, bem como a sua grande mutação de costumes na Modernidade, são outros elementos essenciais na compreensão de um conjunto que interessa estudar na perspetiva da centralidade do poder régio. Para nós ficou claro que a influência religiosa se expressou de maneira significativa na ação governativa do Rei Sol, sustentando a crença de um poder de origem divina, levada a cabo por um conjunto de teólogos católicos. Bossuet, nome inquestionável na defesa deste ideal, teve o cuidado na sua obra magna: Politica tirada das sagradas escrituras, de confirmar, só através do seu título, esta osmose que levamos a cabo de justificar.

O nosso trabalho pretende também dar continuidade a um estudo mais rigoroso das cerimónias e com isso contribuir para um aprofundamento da figura de Luís XIV e do seu período social. Cremos ainda na importância destes estudos para um melhor contributo à História da Arte, da Cultura, da Política e das Mentalidades, abrindo horizontes de pesquisa para lá do espaço europeu com o intuito de encontrar semelhanças em outras culturas e outros espaços religiosos.

Para nós que estudamos a História, não como juízes, mas como meros observadores, temos a certeza de que esta figura contribui para um imenso legado que nos deve exortar a preservá-lo, a estudá-lo e sobretudo, o que poderá ser menos fácil, bem interpretá-lo. A historiografia é assim enriquecida na medida que souber esgrimir as suas fontes e ao mesmo tempo compreender que ideias que perseguiam os vultos que as constituíram. Luís XIV foi apelidado de "O Grande", e de facto é outro título que se traduz não só no seu imenso reinado cronológico, bem como em todas as suas obras. Citando novamente Maquiavel, ao Rei Sol poderia muito bem caber-lhe o parágrafo: "Não há nada que torne um príncipe tão estimado como concluir com êxito grandes e magnânimas obras e dar exemplos dignos de ficarem na memória"92.

\footnotetext{
${ }^{92}$ MAQUIAVEL, Nicolau - O príncipe. Lisboa: Europa-América, 1972, p. 116.
} 


\section{Fontes}

BOSSUET, Jacques Benigne - Politica estratta dalle proprie parole della sacra scrittura. Veneza: Grabiello Ertz, 1714.

COCHEM, Martinho - Explicação da Santa Missa. Bahia: Tipografia de São Francisco, 1914

IGREJA CATÓLICA - Bautisterio, e ceremonial dos Sacramentos da Sancta Madre Igreja

Romana. Emendado e acrescentado em muitas cousas nesta ultima impressam, conforme o Cathecismo, \& Ritual Romano. Coimbra: Oficina de João Antunes, 1698.

IGREJA CATÓLICA - Concilio de Trento.

IGREJA CATÓLICA - Breviarium Romanum ex decreto Sacrosancti Concilii Tridentini.

Roma: Editio Novissima Juxta Typicam, 1901.

IGREJA CATÓLICA - Missale Romanum ex decreto Sacrosancti Concilii Tridentini. Tours:

Sumptibus et typis Mame (Sacrae Rituum Congregationis Typographorum), 1957.

IGREJA CATÓLICA - Pontificale Romanum ex decreto Sacrosancti Concilii Tridentini.

Tours: Laudate Dominum Liturgical Editions, 1991.

IGREJA CATÓLICA - Rituale Romanum ex decreto Sacrosancti Concilii Tridentini. Roma:

Editio Novissima Juxta Typicam, 1901.

LUIS XIV - Memorias sobre el arte de gobernar. Madrid: Espasa-Calpe, 1947.

MAQUIAVEL, Nicolau - Da arte da guerra. Porto Alegre: L\&PM, 2011.

MAQUIAVEL, Nicolau - O príncipe. Lisboa: Europa-América, 1972.

PIO V, Papa - Bula Quo Primum Tempore. São Paulo: Monfort, Associação Cultural, 2016.

Disponível

em

WWW: $<$ http://www.montfort.org.br/bra/documentos/decretos/quoprimum/>.

SAINT-SIMON, Louis de Rouvroy, Duc de - Mémoires sur le règne de Louis XIV et la Régence: extraits. Paris: Librairie Larousse, s.d..

\section{Fontes Iconográficas}

CHAMPAIGNE, Philippe De - Cardinal Richelieu, 1642-1585. Londres: Royal Collection Trust. Disponível em WWW:<URL:https://www.rct.uk/collection/404757/armandcardinal-richelieu-1585-1642>.

JOUVENET, Jean - Louis XIV guérit les scrofuleux. Disponível em WWW:<URL:https://www.altesses.eu/princes max.php?image $=4284 \mathrm{f4c556}>$.

RIGAUD, Hyacinthe - Louis XIV, roi de France (1638-1715). Paris: Musée du Louvre. Disponível em WWW:<URL:http://collections.chateauversailles.fr/\#8142b80a-c46d$\underline{421 \mathrm{~b}-81 \mathrm{e} 3-145 \mathrm{~d} 3 \mathrm{ed} 90 \mathrm{fa} 0}>$. 
VERNET, Horace - Pie VIII porté dans la basilique de Saint-Pierre à Rome, 1829. Versailles: Châteaux de Versailles et de Trianon. Disponível em WWW:<URL: http://collections.chateauversailles.fr/\#19b3836b-3520-4c58-b892-8900d62bbe37>.

\section{Bibliografia}

ALMEIDA, Ricardo Coutinho de - O Absolutismo Régio em França no Reinado de Luís XIV. Coimbra: [Edição do Autor], 2017.

$\mathrm{BLOCH}$, Marc - Os reis taumaturgos, o caráter sobrenatural do poder régio França e Inglaterra. São Paulo: Companhia das letras, 1993.

BONNEY, Richard - O Absolutismo. Mem Martins: Publicações Europa América, 1989.

BURKE, Peter - A construção de Luís XIV. Casal de Cambra: Caleidoscópio, 2007.

CABANNE, Pierre - A arte clássica e o barroco. Lisboa: Edições 70, 2001.

CAMPBELL, Peter Robert - Luís XIV. Lisboa: Editorial Presença, 2009.

CHRISTIAN, Biet - Les miroirs du soleil: le roi Louis XIV et ses artistes. Paris: Gallimard, 2000.

COELHO, António - Curso de liturgia Romana. Braga: Pax Livraria litúrgica, 1941.

DOMINGUES, Joelza Ester - Retrato de Luís XIV: ícone do absolutismo monárquico - Ensinar História, 24 Mar. 2015. [Em linha]. Disponível em WWW:<URL: https://web.archive.org/web/20210703135950/https://ensinarhistoria.com.br/o-retratodo-absolutismo-monarquico/>.

ELIAS, Norbert - A sociedade de corte. Lisboa: Editorial Estampa, 1987.

LAVISSE, Ernest - Louis XIV. La Fronde. Le Roi. Colbert. Histoire de France. Paris: Hachette, 1905.

MANDROU, Robert - Louis XIV: en son temps: 1661-1715. Paris: Presses Universitaires de France, 1973.

MARAVALL, José António - A cultura do Barroco. Lisboa: Instituto superior de novas profissões, 1997.

MONTESQUIEU, Charles Louis de - Do Espírito das Leis. São Paulo: Abril Cultural, 1973.

PRATER, Andreas - A pintura do Barroco. Lisboa: Taschen, 1997.

RIVIÈRE, Claude - As liturgias políticas. Rio de Janeiro: Imago Editora, 1989.

SOUSA, Ivo Carneiro de - História de Portugal moderno: economia e sociedade. Lisboa: Universidade Aberta, 1996. 


\section{Anexos}

\section{Comparação entre os momentos rituais da liturgia Tridentina e das liturgias do Trono.}

\section{Quadro 1 - Ritos com base no Pontificale Romanum ex decreto Sacrosancti Concilii Tridentini.}

Tours: Laudate Dominum, 1991.

\begin{tabular}{|c|c|c|c|c|}
\hline $\begin{array}{l}\text { N.o de } \\
\text { página }\end{array}$ & $\begin{array}{l}\text { Título do } \\
\text { Rito }\end{array}$ & Tipologia & Breve descrição & $\begin{array}{l}\text { Relação } \\
\text { Coroação/ } \\
\text { Sagração }\end{array}$ \\
\hline 105 & $\begin{array}{l}\text { Coroação } \\
\text { dos Reis }\end{array}$ & $\begin{array}{l}\text { Rubrica inicial - } \\
\text { 1. Jejum. }\end{array}$ & $\begin{array}{c}\text { O Rei fazia Jejum durante três dias na Quarta, Sexta e no Sábado. "Reza } \\
\text { devotamente e no Domingo era coroado." }\end{array}$ & 21 \\
\hline 105 & $\begin{array}{l}\text { Coroação } \\
\text { dos Reis }\end{array}$ & $\begin{array}{l}\text { Rubrica inicial - } \\
\text { 2. Preparação da } \\
\quad \text { catedral. }\end{array}$ & $\begin{array}{l}\text { O Rei era coroado na catedral principal do Reino, que se ornava da melhor } \\
\text { forma possível com magnificiência e esplendor e era coroado pelo clérigo } \\
\text { mais importante do Reino. }\end{array}$ & 22 \\
\hline 105 & $\begin{array}{l}\text { Coroação } \\
\text { dos Reis }\end{array}$ & $\begin{array}{l}\text { Rubrica inicial - } \\
\text { 3. Preparação do } \\
\text { altar e das alfaias }\end{array}$ & $\begin{array}{l}\text { Segundo as normas para a missa pontifical, com a credência devidamente } \\
\text { preparada. No altar principal coloca-se a Espada, A Coroa ao centro, o cetro } \\
\text { real e o Óleo dos catecúmenos. Depois dispor o trono de frente para o altar } \\
\text { e uma cred encia com os ornamentos régios. }\end{array}$ & s/corresp. \\
\hline 105 & $\begin{array}{l}\text { Coroação } \\
\text { dos Reis }\end{array}$ & $\begin{array}{l}\text { Interrogação à } \\
\text { Igreja de Deus. }\end{array}$ & $\begin{array}{l}\text { O bispo principal interroga se o candidato ao trono é digno desse ofício e se } \\
\text { tem a legitimidade. }\end{array}$ & 24 \\
\hline 105 & $\begin{array}{l}\text { Coroação } \\
\text { dos Reis }\end{array}$ & $\begin{array}{l}\text { Início da } \\
\text { cerimónia ritual }\end{array}$ & $\begin{array}{l}\text { O Rei senta-se entre dois bispos, tendo o mais ancião do seu lado direito e } \\
\text { de frente para ele o bispo principal que proseegue os ritos iniais. }\end{array}$ & s/corresp. \\
\hline 106 & $\begin{array}{l}\text { Coroação } \\
\text { dos Reis }\end{array}$ & $\begin{array}{l}\text { Primeiro parte do } \\
\text { juramento }\end{array}$ & $\begin{array}{l}\text { O Rei ajoelha-se diante do bispo e faz o primeiro juramnto. "Ego N. Deo } \\
\text { annuénte, futúrus Rex N. profiteor, et promítto coram Deo, et Angelis ejus, } \\
\text { deínceps legem, justítiam et pacem Ecclésiæ Dei, populóque mihi subjécto, } \\
\text { pro posse et nosse, fácere ac serváre, salvo condígno misericórdiæ Dei } \\
\text { respéctu, sicut in consílio fidélium meórum mélius pótero inveníre. } \\
\text { Pontificibus quoque Ecclesiárum Dei, condígnum et canónicum honórem } \\
\text { exhibére; atque ea, quæ ab Imperatóribus, et Régibus Ecclésiis colláta, et } \\
\text { réddita sunt, inviolabíliter observáre. Abbátibus, Comítibus et Vasáliis meis } \\
\text { cóngruum honórem, secúndum consílium fidélium meórum præstáre." }\end{array}$ & 25 \\
\hline 106 & $\begin{array}{l}\text { Coroação } \\
\text { dos Reis }\end{array}$ & $\begin{array}{l}\text { Segunda parte do } \\
\text { juramento }\end{array}$ & $\begin{array}{l}\text { O Rei com a mão nos santos evangelhos jura manter a Fé Católica } \\
\text { novamente e pede ajuda a Deus para exercer a sua função sagrada. }\end{array}$ & 26 \\
\hline 106 & $\begin{array}{l}\text { Coroação } \\
\text { dos Reis }\end{array}$ & $\begin{array}{l}\text { Osculo da mão do } \\
\text { bispo }\end{array}$ & $\begin{array}{c}\text { O Rei beija a mão do bispo como sinal de saubmissão do poder temporal ao } \\
\text { espiritual. }\end{array}$ & $\mathrm{s} /$ corresp. \\
\hline $\begin{array}{l}106- \\
107\end{array}$ & $\begin{array}{l}\text { Coroação } \\
\text { dos Reis }\end{array}$ & $\begin{array}{l}\text { Primeira Oração } \\
\text { da sagração }\end{array}$ & O Bispo Principal ora solenemente sobre o Rei que permanece ajoelhado & s/corresp. \\
\hline 107 & $\begin{array}{l}\text { Coroação } \\
\text { dos Reis }\end{array}$ & $\begin{array}{l}\text { Ladainha de } \\
\text { Todos os Santos }\end{array}$ & $\begin{array}{c}\text { Neste momento o bispo dirije-se ao faldistória e junmtamente com todo o } \\
\text { clero e o Rei prostrado no presbitério cantam solenemente a ladainha de } \\
\text { Todos os Santos. }\end{array}$ & 31 \\
\hline 107 & $\begin{array}{l}\text { Coroação } \\
\text { dos Reis }\end{array}$ & $\begin{array}{l}\text { Sagração Ritual } \\
\text { durante a ladainha }\end{array}$ & $\begin{array}{l}\text { O Bispo na parte final das rogações da ladinha levanta-se e de forma } \\
\text { majestosa benze o Rei } 5 \text { vezes consagrando-o e santificando-o perante } \\
\text { Deus. }\end{array}$ & 32 \\
\hline 108 & $\begin{array}{l}\text { Coroação } \\
\text { dos Reis }\end{array}$ & $\begin{array}{l}\text { Unção com o } \\
\text { Óleo dos } \\
\text { Catecumenos }\end{array}$ & $\begin{array}{l}\text { O bispo principal unge o rei na testa, nos obros, entre os cotovelos, todo o } \\
\text { braço direito e as mãos. }\end{array}$ & 37 \\
\hline 108 & $\begin{array}{l}\text { Coroação } \\
\text { dos Reis }\end{array}$ & $\begin{array}{l}\text { Início da missa } \\
\text { pontifical até ao } \\
\text { Aleluia }\end{array}$ & $\begin{array}{l}\text { O bispo, clero e o rei começam a Missa Tridentina com a confissão e } \\
\text { seuguem os rituais prórios da pontifical até ao Evangelo. }\end{array}$ & s/corresp. \\
\hline 109 & $\begin{array}{l}\text { Coroação } \\
\text { dos Reis }\end{array}$ & $\begin{array}{l}\text { Entrega da } \\
\text { Regalia - } 1 \\
\text { Espada }\end{array}$ & $\begin{array}{l}\text { Neste momento o Rei recebe a espada que estava no altar das mãos do } \\
\text { bispo que faz uma oração solene, onde se diz que com aquela espada o Rei } \\
\text { tem o dever de defender o reino e a Fé Católica. }\end{array}$ & 29 \\
\hline $\begin{array}{c}109- \\
110\end{array}$ & $\begin{array}{l}\text { Coroação } \\
\text { dos Reis }\end{array}$ & $\begin{array}{l}\text { Entrega da } \\
\text { Regalia - } 2 . \\
\text { Coroação }\end{array}$ & $\begin{array}{l}\text { Momento central, o bispo coroa solenemente o Rei que está já sentado no } \\
\text { Trono dizendo: "Accipe Corónam regni, quæ, licet ab indígnis, } \\
\text { Episcopórum tamen mánibus cápiti tuo impónitur: In nómine Pa + tris, et Fí } \\
\text { + lii, et Spíritus + Sancti; quam sanctitátis glóriam, et honórem, et opus } \\
\text { fortitúdinis, significáre intélligas, et per hanc te partícipem ministérii nostri } \\
\text { non ignóres. Ita ut sicut nos in interióribus pastóres, rectorésque animárum } \\
\text { intellígimur, ita et tu in exterióribus verus Dei cultor, strenuúsque contra } \\
\text { omnes adversitátes Ecclésiæ Christi defénsor assístas, regníque tibi, a Deo } \\
\text { dati, et per officium nostræ benedictiónis in vice Apostolórum, omniumque } \\
\text { Sanctórum, regímini tuo commíssi útilis execútor, proficuúsque regnátor } \\
\text { semper appáreas, ut inter gloriósos athlétas, virtútum gemmis ornátus, et } \\
\text { præmio sempitérnæ felicitátis coronátus. cum Redemptóre, ac Salvatóre } \\
\text { nostro Jesu Christo, cujus nomen, vicémque gestáre créderis, sine fine } \\
\text { gloriéris: Qui vivit, et ímperat Deus cum Patre et Spíritu Sancto in sǽcula } \\
\text { sæculórum. R. Amen. }\end{array}$ & 29 \\
\hline 110 & $\begin{array}{l}\text { Coroação } \\
\text { dos Reis }\end{array}$ & $\begin{array}{l}\text { Entrega da } \\
\text { Regalia - } 3 \text {. } \\
\text { Ceptro e Globus } \\
\text { Crucifiger }\end{array}$ & $\begin{array}{l}\text { É o momento de entrgar o cetro que é acompanhado de extensa oração e do } \\
\text { Globus Crucifiger que representa o mundo regido pela Cruz de Cristo. }\end{array}$ & 29 \\
\hline
\end{tabular}




\begin{tabular}{|c|c|c|c|c|}
\hline $\begin{array}{l}\text { N. de } \\
\text { página }\end{array}$ & $\begin{array}{l}\text { Título do } \\
\text { Rito }\end{array}$ & Tipologia & Breve descrição & $\begin{array}{l}\text { Relação } \\
\text { Coroação/ } \\
\text { Sagração }\end{array}$ \\
\hline 110 & $\begin{array}{l}\text { Coroação } \\
\text { dos Reis }\end{array}$ & Te Deum & Segue-se imediatamento o Te Deum soleníssimo & s/corresp. \\
\hline 110 & $\begin{array}{l}\text { Coroação } \\
\text { dos Reis }\end{array}$ & $\begin{array}{l}\text { Continuação da } \\
\text { Missa pontifical. }\end{array}$ & O rito da missa é retomado a partir do ofertório. & $\mathrm{s} /$ corresp. \\
\hline 111 & $\begin{array}{l}\text { Coroação } \\
\text { dos Reis }\end{array}$ & $\begin{array}{l}\text { Comunhão do Rei } \\
\text { (Communio) }\end{array}$ & $\begin{array}{l}\text { Na altura da comunhão o Rei ajoelha-se beija a mão do bispo e depois } \\
\text { comunga o corpo e sangue de Cristo. }\end{array}$ & s/corresp. \\
\hline 111 & $\begin{array}{l}\text { Coroação } \\
\text { dos Reis }\end{array}$ & $\begin{array}{l}\text { Post Comunio e } \\
\text { benedictio }\end{array}$ & $\begin{array}{l}\text { Este rito final encerra o ritual com a benção solene tripartida do bispo, } \\
\text { seguida de uma procissão de saída soleníssima, onde o clero sai com os } \\
\text { hábitos corais e o Rei já com o seu manto sagrado. }\end{array}$ & s/corresp. \\
\hline 49 & $\begin{array}{l}\text { Sagração } \\
\text { Episcopal }\end{array}$ & $\begin{array}{l}\text { Rubrica inicial - } \\
\text { 1. jejum. }\end{array}$ & $\begin{array}{c}\text { O elito ao Sumo sacerdócio deveria fazer jejum um dia antes da sagração } \\
\text { episcopal }\end{array}$ & 1 \\
\hline 49 & $\begin{array}{l}\text { Sagração } \\
\text { Episcopal }\end{array}$ & $\begin{array}{l}\text { Rubrica inicial - } \\
\text { 2. Preparação da } \\
\text { catedral. }\end{array}$ & $\begin{array}{l}\text { A igrej acatedral é solenemente preparada com as alfaias necessárias para } \\
\text { os ritos pontificais. }\end{array}$ & 2 \\
\hline $49-50$ & $\begin{array}{l}\text { Sagração } \\
\text { Episcopal }\end{array}$ & $\begin{array}{l}\text { Rubrica inicial - } \\
\text { 3. Hierrarquia }\end{array}$ & $\begin{array}{l}\text { A rubrica inicial estabelece uma rigorosa hierarquia dos clérigos que vão } \\
\text { participar na cerimónia e a sua indumentária. }\end{array}$ & s/corresp. \\
\hline 50 & $\begin{array}{l}\text { Sagração } \\
\text { Episcopal }\end{array}$ & Interrogatio & $\begin{array}{l}\text { O Bispo pergunta ao diácono se este tem o mandato apostólico Papal para } \\
\text { se realizar o solene rito e se o eleito é digno do Sumo Sacerdócio. }\end{array}$ & 4 \\
\hline 50 & $\begin{array}{l}\text { Sagração } \\
\text { Episcopal }\end{array}$ & $\begin{array}{l}\text { Primeira parte do } \\
\text { Juramento }\end{array}$ & O candidato faz a profissão de Fé tridentina & 6 \\
\hline 51 & $\begin{array}{l}\text { Sagração } \\
\text { Episcopal }\end{array}$ & $\begin{array}{l}\text { Segunda parte do } \\
\text { juramento }\end{array}$ & O candidato faz o juramento sobre os evangelhos & 7 \\
\hline $52-54$ & $\begin{array}{l}\text { Sagração } \\
\text { Episcopal }\end{array}$ & $\begin{array}{l}\text { Exame } \\
\text { interrogatório }\end{array}$ & $\begin{array}{l}\text { O bispoo consagrante interroga o candidato sobre os artigos de Fé e os } \\
\text { dogmas }\end{array}$ & $\mathrm{s} /$ corresp. \\
\hline 55 & $\begin{array}{l}\text { Sagração } \\
\text { Episcopal }\end{array}$ & Oratio Prima & $\begin{array}{l}\text { Os três bispos mais o elito retiram-se para uma capela prelatícia e recitam } \\
\text { em privado determinados salmos bíblicos. }\end{array}$ & s/corresp. \\
\hline 55 & $\begin{array}{l}\text { Sagração } \\
\text { Episcopal }\end{array}$ & $\begin{array}{l}\text { Investidura com a } \\
\text { cruz e estola }\end{array}$ & O eleito é investido com a cruz peitoral e a estola & $14,15,16$ \\
\hline 55 & $\begin{array}{l}\text { Sagração } \\
\text { Episcopal }\end{array}$ & Ad Missam & A missa tridentina prossegue até ao tracto e sequ encia & $\mathrm{s} /$ corresp. \\
\hline 56 & $\begin{array}{l}\text { Sagração } \\
\text { Episcopal }\end{array}$ & Ladainhas & São cantadas as ladainhas de todos os santos & 10 \\
\hline 56 & $\begin{array}{l}\text { Sagração } \\
\text { Episcopal }\end{array}$ & $\begin{array}{l}\text { Sagração Ritual } \\
\text { durante a ladainha }\end{array}$ & $\begin{array}{l}\text { O Bispo na parte final das rogações da ladinha levanta-se e de forma } \\
\text { majestosa benze o eleito } 5 \text { vezes consagrando-o e santificando-o perante } \\
\text { Deus. }\end{array}$ & 11 \\
\hline 56 & $\begin{array}{l}\text { Sagração } \\
\text { Episcopal }\end{array}$ & Insuflatio & O Bispo sopra sobre o elito e diz para ele receber o Espírito Santo. & $\mathrm{s} /$ corresp. \\
\hline 56 & $\begin{array}{l}\text { Sagração } \\
\text { Episcopal }\end{array}$ & Responsório & O Bispo entoa o responsória antes do prefácio & $\mathrm{s} /$ corresp. \\
\hline 56 & $\begin{array}{l}\text { Sagração } \\
\text { Episcopal }\end{array}$ & $\begin{array}{l}\text { Prefácio da } \\
\text { consagração }\end{array}$ & O Bispo entoa o Prefácio solene de sagração dos bispos. & s/corresp. \\
\hline 57 & $\begin{array}{l}\text { Sagração } \\
\text { Episcopal }\end{array}$ & $\begin{array}{l}\text { Véni creátor } \\
\text { Spíritus }\end{array}$ & Entoua-se o hino ao Espírito Santo segundo as disposições tridentinas & $\mathrm{s} /$ corresp. \\
\hline 57 & $\begin{array}{l}\text { Sagração } \\
\text { Episcopal }\end{array}$ & $1^{\circ}$ Unção & O bipo unge o elito na testa com o óleo do Crisma & 12 \\
\hline 57 & $\begin{array}{l}\text { Sagração } \\
\text { Episcopal }\end{array}$ & $\begin{array}{l}\text { Consagração da } \\
\text { cabeça }\end{array}$ & O Bipo benze tr es vezes a cabeça do elito. & s/corresp. \\
\hline 57 & $\begin{array}{l}\text { Sagração } \\
\text { Episcopal }\end{array}$ & $\begin{array}{l}\text { Exorcismo e } \\
\text { Oratio }\end{array}$ & $\begin{array}{l}\text { O Bipo reza um exorcismo e oração ancestral sobre o candidato que lhe } \\
\text { investe de poder especial para exorcizar os demónios de forma ordinária. }\end{array}$ & s/corresp. \\
\hline 57 & $\begin{array}{l}\text { Sagração } \\
\text { Episcopal }\end{array}$ & $2^{\circ}$ Unção & O Bispo unge as mãos do elito com o óleo do Crisma & s/corresp. \\
\hline 57 & $\begin{array}{l}\text { Sagração } \\
\text { Episcopal }\end{array}$ & $\begin{array}{l}\text { Aspersão da água } \\
\text { exorcizada }\end{array}$ & O bispo asperge água benta e exorcizada sobre o elito. & s/corresp. \\
\hline
\end{tabular}




\section{Quadro 2 - Ritos com base em Saint Simon - Mémoires complets et authentiques du duc de} Saint-Simon sur le siècle de Louis XIV et la Régence. Paris: 1856-1858.

\begin{tabular}{|c|c|c|c|c|c|c|}
\hline $\begin{array}{l}\text { N. }{ }^{\circ} \text { de } \\
\text { página }\end{array}$ & $\begin{array}{l}\text { Título } \\
\text { do Rito }\end{array}$ & Tipologia & Breve descrição & $\begin{array}{l}\text { Relação com } \\
\text { a Missa }\end{array}$ & Tip. do Rito & Estrutura \\
\hline $\begin{array}{l}\text { Vol. } 11, \\
\text { Cap. } \\
\text { LXXVIII }\end{array}$ & $\begin{array}{l}\text { Almoço } \\
\text { do Rei }\end{array}$ & $\begin{array}{l}\text { Pessoas } \\
\text { admitidas }\end{array}$ & $\begin{array}{l}\text { Um grupo restrito, era possível pedir para } \\
\text { assistir ao primeiro Cavaleiro da Câmara e } \\
\text { depois o Rei recusava ou aceitava. Os } \\
\text { clérigos que não fossem bispos ou cardeais } \\
\text { não podiam assistir. " O número de pessoas } \\
\text { de quem foi feita uma escolha foi, no } \\
\text { entanto, muito limitado. Mesmo um posto } \\
\text { militar muito alto não era suficiente. M. de } \\
\text { Vauban, no cerco de Namur, ficou } \\
\text { impressionado com a distinção." }\end{array}$ & s/corresp. & s/corresp. & s/corresp. \\
\hline $\begin{array}{l}\text { Vol. } 11, \\
\text { Cap. } \\
\text { LXXVIII }\end{array}$ & $\begin{array}{l}\text { Almoço } \\
\text { do Rei }\end{array}$ & $\begin{array}{l}\text { Uso } \\
\text { obrigatório } \\
\text { de chapéu }\end{array}$ & $\begin{array}{l}\text { "Nessas refeições, todos estavam cobertos; } \\
\text { seria uma falta de respeito, da qual a pessoa } \\
\text { seria imediatamente informada, se não } \\
\text { tivesse mantido o chapéu na cabeça." }\end{array}$ & s/corresp. & s/corresp. & s/corresp. \\
\hline $\begin{array}{l}\text { Vol. } 11, \\
\text { Cap. } \\
\text { LXXVIII }\end{array}$ & $\begin{array}{l}\text { Almoço } \\
\text { do Rei }\end{array}$ & $\begin{array}{l}\text { Descobrir a } \\
\text { cabeça }\end{array}$ & $\begin{array}{l}\text { Quando o Rei fala-se para determinada } \\
\text { pessoa ou a pessoa solicitava falar com o } \\
\text { Rei }\end{array}$ & s/corresp. & s/corresp. & s/corresp. \\
\hline $\begin{array}{l}\text { Vol. } 11, \\
\text { Cap. } \\
\text { LXXVIII }\end{array}$ & $\begin{array}{l}\text { Almiço } \\
\text { do Rei }\end{array}$ & $\begin{array}{l}\text { Colocar a } \\
\text { mão no } \\
\text { chapéu }\end{array}$ & $\begin{array}{c}\text { Acontecia quando se falava com um Par de } \\
\text { Sangue da família real, para distinguir do } \\
\text { Rei. }\end{array}$ & s/corresp. & s/corresp. & s/corresp. \\
\hline $\begin{array}{l}\text { Vol. } 11, \\
\text { Cap. } \\
\text { LXXVIII }\end{array}$ & $\begin{array}{l}\text { Almoço } \\
\text { do Rei }\end{array}$ & $\begin{array}{l}\text { O assento } \\
\text { do Rei }\end{array}$ & $\begin{array}{c}\text { O Rei ficava numa poltrono parecida a um } \\
\text { trono sagrado. }\end{array}$ & s/corresp. & s/corresp. & s/corresp. \\
\hline $\begin{array}{l}\text { Vol. } 11, \\
\text { Cap. } \\
\text { LXXVIII }\end{array}$ & $\begin{array}{l}\text { Almoço } \\
\text { do Rei }\end{array}$ & $\begin{array}{l}\text { Os assentos } \\
\text { dos } \\
\text { princípes de } \\
\text { Sangue }\end{array}$ & $\begin{array}{l}\text { "Os convidados, inclusive o Delfim, tinham } \\
\text { assentos, com costas de couro preto de } \\
\text { marrocos." }\end{array}$ & s/corresp. & s/corresp. & s/corresp. \\
\hline $\begin{array}{l}\text { Vol. } 11, \\
\text { Cap. } \\
\text { LXXVIII }\end{array}$ & $\begin{array}{l}\text { Almoço } \\
\text { do Rei }\end{array}$ & $\begin{array}{l}\text { Da forma de } \\
\text { servir o Rei }\end{array}$ & $\begin{array}{l}\text { O Rei era servido como numa missa, os } \\
\text { pratos eram passados de mãos em mãos do } \\
\text { menos importante para o mais digno nobre } \\
\text { que lhe levava a comida à mesa. Nota: Na } \\
\text { missa tridentina as galhetas com a água e o } \\
\text { vinho e demais elementos litúrgicos são } \\
\text { passados dos acólitos menores, para os } \\
\text { maiores como o cerimoniário e, se for esse o } \\
\text { caso, do diácono e subdiácono até chegar ao } \\
\text { celebrante. }\end{array}$ & s/corresp. & s/corresp. & s/corresp. \\
\hline $\begin{array}{l}\text { Vol. } 11, \\
\text { Cap. } \\
\text { LXXVIII }\end{array}$ & $\begin{array}{l}\text { Almoço } \\
\text { do Rei }\end{array}$ & $\begin{array}{l}\text { Da forma de } \\
\text { comer }\end{array}$ & $\begin{array}{l}\text { O Rei comia com a mão direita, depois de } \\
\text { lhe haverem partido a comida. }\end{array}$ & s/corresp. & $\mathrm{s} /$ corresp. & s/corresp. \\
\hline $\begin{array}{l}\text { Vol. 11, } \\
\text { Cap. } \\
\text { LXXVIII }\end{array}$ & $\begin{array}{c}\text { O } \\
\text { levantar } \\
\text { do Rei }\end{array}$ & $\begin{array}{l}\text { O primeiro } \\
\text { acoradar }\end{array}$ & $\begin{array}{l}\text { Era feito pelo mordomo camareiro do Rei às } \\
\qquad 8 \mathrm{~h} \text { da manhã. }\end{array}$ & 1 & $\begin{array}{c}\text { Cum lavat } \\
\text { manus } \\
\text { (Sacerdotalibus } \\
\text { paramentis) }\end{array}$ & $\begin{array}{l}\text { Praeparatio } \\
\text { ad Missam }\end{array}$ \\
\hline $\begin{array}{l}\text { Vol. } 11, \\
\text { Cap. } \\
\text { LXXVIII }\end{array}$ & $\begin{array}{c}\text { O } \\
\text { levantar } \\
\text { do Rei }\end{array}$ & $\begin{array}{l}\text { O primeiro } \\
\text { acoradar }\end{array}$ & $\begin{array}{l}\text { Era feito pelo mordomo camareiro do Rei às } \\
\qquad 8 \mathrm{~h} \text { da manhã. }\end{array}$ & 24 & $\begin{array}{c}\text { Ad Missa } \\
\text { (Sinal da Cruz) }\end{array}$ & $\begin{array}{l}\text { Ante } \\
\text { Missa }\end{array}$ \\
\hline $\begin{array}{l}\text { Vol. 11, } \\
\text { Cap. } \\
\text { LXXVIII }\end{array}$ & $\begin{array}{c}\text { O } \\
\text { levantar } \\
\text { do Rei }\end{array}$ & $\begin{array}{l}\text { A grande } \\
\text { entrada }\end{array}$ & $\begin{array}{c}\text { Entrava primeiro o médico mor, o cirurgião } \\
\text { mor e uma enfermeira para saber se o Rei se } \\
\text { encontrava bem. Depois entram logo os } \\
\text { princípes de sangue. O camareiro mor abria } \\
\text { as cortinas que tinha sido fechadas da cama } \\
\text { do Rei. }\end{array}$ & 1 & $\begin{array}{l}\text { Cum lavat } \\
\text { manus } \\
\text { (Sacerdotalibus } \\
\text { paramentis) }\end{array}$ & $\begin{array}{l}\text { Praeparatio } \\
\text { ad Missam }\end{array}$ \\
\hline $\begin{array}{l}\text { Vol. 11, } \\
\text { Cap. } \\
\text { LXXVIII }\end{array}$ & $\begin{array}{c}\text { O } \\
\text { levantar } \\
\text { do Rei }\end{array}$ & $\begin{array}{l}\text { A grande } \\
\text { entrada }\end{array}$ & $\begin{array}{c}\text { Entrava primeiro o médico mor, o cirurgião } \\
\text { mor e uma enfermeira para saber se o Rei se } \\
\text { encontrava bem. Depois entram logo os } \\
\text { princípes de sangue. O camareiro mor abria } \\
\text { as cortinas que tinha sido fechadas da cama } \\
\text { do Rei. }\end{array}$ & 24 & $\begin{array}{c}\text { Ad Missa } \\
\text { (Sinal da Cruz) }\end{array}$ & $\begin{array}{l}\text { Ante } \\
\text { Missa }\end{array}$ \\
\hline $\begin{array}{l}\text { Vol. } 11, \\
\text { Cap. } \\
\text { LXXVIII }\end{array}$ & $\begin{array}{c}\text { O } \\
\text { levantar } \\
\text { do Rei }\end{array}$ & $\begin{array}{l}\text { Aspersão da } \\
\text { água benta }\end{array}$ & $\begin{array}{l}\text { O camareiro mor apresenta ao Rei Água } \\
\text { Benta para se benzer e um livro de orações. }\end{array}$ & s/corresp. & s/corresp. & s/corresp. \\
\hline $\begin{array}{l}\text { Vol. 11, } \\
\text { Cap. } \\
\text { LXXVIII }\end{array}$ & $\begin{array}{c}\text { O } \\
\text { levantar } \\
\text { do Rei }\end{array}$ & $\begin{array}{l}\text { Ida para o } \\
\text { gabinete do } \\
\text { conselho }\end{array}$ & $\begin{array}{l}\text { O Rei desloca-se com os príncipes de sangue } \\
\text { para um oratório no gabinete do conselho, } \\
\text { junto ao seu quarto, onde de forma breve } \\
\text { realiza um ato religioso de oração, ainda de } \\
\text { roupão de dormir. }\end{array}$ & 24 & $\begin{array}{c}\text { Ad Missa } \\
\text { (Sinal da Cruz) }\end{array}$ & $\begin{array}{l}\text { Ante } \\
\text { Missa }\end{array}$ \\
\hline
\end{tabular}




\begin{tabular}{|c|c|c|c|c|c|c|}
\hline $\begin{array}{l}\text { N.o de } \\
\text { página }\end{array}$ & $\begin{array}{l}\text { Título } \\
\text { do Rito }\end{array}$ & Tipologia & Breve descrição & $\begin{array}{l}\text { Relação com } \\
\text { a Missa }\end{array}$ & Tip. do Rito & Estrutura \\
\hline $\begin{array}{l}\text { Vol. } 11, \\
\text { Cap. } \\
\text { LXXVIII }\end{array}$ & $\begin{array}{l}\text { O } \\
\text { levantar } \\
\text { do Rei }\end{array}$ & $\begin{array}{l}\text { Entra } \\
\text { novamento } \\
\text { no quarto }\end{array}$ & Entra para se vestir & 25 & $\begin{array}{l}\text { Ad Missa } \\
\text { (Salmo 42) }\end{array}$ & $\begin{array}{l}\text { Ante } \\
\text { Missa }\end{array}$ \\
\hline $\begin{array}{l}\text { Vol. } 11, \\
\text { Cap. } \\
\text { LXXVIII }\end{array}$ & $\begin{array}{l}\text { O } \\
\text { levantar } \\
\text { do Rei }\end{array}$ & $\begin{array}{l}\text { Segunda } \\
\text { entrada }\end{array}$ & $\begin{array}{l}\text { Entram outros previlegiados e clérigos para } \\
\text { verem o Rei a vestir-se e ajudá-lo como na } \\
\text { missa. Trata-se um ritual. Sabemos que o } \\
\text { Rei calçava os seus sapatos sozinho: } \\
\text { "imediatamente depois, outros cortesãos } \\
\text { privilegiados entraram, e então todos, a } \\
\text { tempo de encontrar o rei calçando os seus } \\
\text { sapatos e meias, pois ele fazia quase tudo } \\
\text { sozinho, com endereço e graça." }\end{array}$ & 26 & $\begin{array}{l}\text { Ad Missa } \\
\text { (Confissão) }\end{array}$ & $\begin{array}{l}\text { Ante } \\
\text { Missa }\end{array}$ \\
\hline $\begin{array}{l}\text { Vol. } 11, \\
\text { Cap. } \\
\text { LXXVIII }\end{array}$ & $\begin{array}{l}\text { O } \\
\text { levantar } \\
\text { do Rei }\end{array}$ & $\begin{array}{l}\text { Sunda } \\
\text { Oração a } \\
\text { Deus }\end{array}$ & $\begin{array}{c}\text { "Assim que se vestiu, orou a Deus, ao lado } \\
\text { da sua cama, onde todos os clérigos } \\
\text { presentes estavam ajoelhados, os cardeais } \\
\text { com almofadas, todos os leigos } \\
\text { permanecendo de pé; e o capitão dos } \\
\text { guardas chegou à balaustrada durante a } \\
\text { oração, após a qual o rei entrou novamente } \\
\text { no seu gabinete." }\end{array}$ & 27 & $\begin{array}{l}\text { Ad Missa } \\
\text { (Confissão do } \\
\text { acólito em } \\
\text { nome do povo) }\end{array}$ & $\begin{array}{l}\text { Ante } \\
\text { Missa }\end{array}$ \\
\hline $\begin{array}{l}\text { Vol. } 11, \\
\text { Cap. } \\
\text { LXXVIII }\end{array}$ & $\begin{array}{l}\text { O } \\
\text { levantar } \\
\text { do Rei }\end{array}$ & $\begin{array}{l}\text { Terceira } \\
\text { entrada }\end{array}$ & $\begin{array}{l}\text { Já no gabinete entre uma multidão de } \\
\text { pessoas a quem o Rei saúde e dá uma série } \\
\text { de ordens para o dia que se inicia. }\end{array}$ & 28 & $\begin{array}{l}\text { Ad Missa } \\
\text { (Subida ao } \\
\text { altar do } \\
\text { Sacerdote) }\end{array}$ & $\begin{array}{l}\text { Ante } \\
\text { Missa }\end{array}$ \\
\hline $\begin{array}{l}\text { Vol. } 11, \\
\text { Cap. } \\
\text { LXXVIII }\end{array}$ & $\begin{array}{l}\text { Decorrer } \\
\text { do dia }\end{array}$ & Audiências & $\begin{array}{l}\text { O Rei recebia por grau de importãncia } \\
\text { personalidades, os ministros e demais } \\
\text { pessoas comuns. }\end{array}$ & s/corresp. & s/corresp. & s/corresp. \\
\hline $\begin{array}{l}\text { Vol. } 11, \\
\text { Cap. } \\
\text { LXXVIII }\end{array}$ & $\begin{array}{l}\text { Decorrer } \\
\text { do dia }\end{array}$ & Missa & $\begin{array}{l}\text { O Rei assitia à missa que era sempre } \\
\text { acompanhada por hinos musicais. Saint } \\
\text { Simon dizz-nos que o Rei nunca assistia à } \\
\text { missa em baixo, mas sempre na tribuna real. }\end{array}$ & s/corresp. & s/corresp. & s/corresp. \\
\hline $\begin{array}{l}\text { Vol. } 11, \\
\text { Cap. } \\
\text { LXXVIII }\end{array}$ & $\begin{array}{l}\text { Decorrer } \\
\text { do dia }\end{array}$ & $\begin{array}{l}\text { Momento } \\
\text { antes do } \\
\text { almoço }\end{array}$ & $\begin{array}{l}\text { "O rei se divertia um pouco ao retornar da } \\
\text { missa. Então a manhã terminou." }\end{array}$ & s/corresp. & s/corresp. & s/corresp. \\
\hline $\begin{array}{l}\text { Vol. } 11, \\
\text { Cap. } \\
\text { LXXVIII }\end{array}$ & $\begin{array}{l}\text { Decorrer } \\
\text { do dia }\end{array}$ & Trade & $\begin{array}{l}\text { "No domingo, e muitas vezes na segunda- } \\
\text { feira, havia um conselho de estado; na terça- } \\
\text { feira um conselho de finanças; na quarta- } \\
\text { feira conselho de estado; no conselho } \\
\text { financeiro de sábado: raramente havia dois } \\
\text { em um dia ou na quinta ou sexta-feira. Uma } \\
\text { ou duas vezes por mês, havia um conselho } \\
\text { de despachos na manhã de segunda-feira. } \\
\text { Todos os ministros estavam sentados de } \\
\text { acordo com a hierarquia, exceto no conselho } \\
\text { de despachos, onde todos estavam, exceto os } \\
\text { filhos da França, o chanceler e o duque de } \\
\text { Beauvilliers." }\end{array}$ & s/corresp. & s/corresp. & s/corresp. \\
\hline $\begin{array}{l}\text { Vol. } 11, \\
\text { Cap. } \\
\text { LXXVIII }\end{array}$ & $\begin{array}{l}\text { Decorrer } \\
\text { do dia }\end{array}$ & $\begin{array}{l}\text { A Quinta- } \\
\text { feira. }\end{array}$ & $\begin{array}{l}\text { Era o dia em que o Rei atendia o povo e os } \\
\text { seus filhos bastardos segundo Saint Simon. }\end{array}$ & s/corresp. & s/corresp. & s/corresp. \\
\hline $\begin{array}{l}\text { Vol. } 11, \\
\text { Cap. } \\
\text { LXXVIII }\end{array}$ & Jantar & $\begin{array}{l}\text { Início ("au } \\
\text { petit } \\
\text { couvert") }\end{array}$ & $\begin{array}{l}\text { "O rei comia sozinho no seu aposento, sobre } \\
\text { uma mesa quadrada em frente à janela do } \\
\text { meio. Era mais ou menos abundante, pois } \\
\text { ele ordenou pela manhã que deveria ser "um } \\
\text { pouco" ou "muito pouco" serviço. Mas } \\
\text { mesmo assim, sempre havia muitos pratos e } \\
\text { três pratos sem contar a fruta. Estando o } \\
\text { jantar pronto, os principais cortesãos } \\
\text { entraram; então todos os que eram } \\
\text { conhecidos; e o cavalheiro da câmara de } \\
\text { serviço informou o rei." }\end{array}$ & s/corresp. & s/corresp. & s/corresp. \\
\hline $\begin{array}{l}\text { Vol. } 11, \\
\text { Cap. } \\
\text { LXXVIII }\end{array}$ & Jantar & $\begin{array}{l}\text { Principes de } \\
\text { sangue e o } \\
\text { Delfim }\end{array}$ & $\begin{array}{l}\text { "Vi, mas muito raramente, o Delfim e os } \\
\text { seus filhos em pé nos jantares, o rei não lhes } \\
\text { oferecia, muitas vezes, um assento. Noutras } \\
\text { ocasiões, quando ele veio de Saint-Cloud, o } \\
\text { rei, ao chegar à mesa, pediu um prato para o } \\
\text { Delfim ou perguntou se ele iria jantar. Se ele } \\
\text { recusou, não houve menção a um assento; se } \\
\text { ele aceitasse, o rei pedia um prato para ele." }\end{array}$ & s/corresp. & s/corresp. & s/corresp. \\
\hline $\begin{array}{l}\text { Vol. } 11, \\
\text { Cap. } \\
\text { LXXVIII }\end{array}$ & Jantar & $\begin{array}{l}\text { A mesa e o } \\
\text { serviço }\end{array}$ & $\begin{array}{l}\text { A mesa era quadrada e o Rei estava numa } \\
\text { das extremidades, "á francesa". Era servido } \\
\text { pelo copeiro mor. }\end{array}$ & s/corresp. & s/corresp. & s/corresp. \\
\hline
\end{tabular}




\begin{tabular}{|c|c|c|c|c|c|c|}
\hline $\begin{array}{l}\text { N.o de } \\
\text { página }\end{array}$ & $\begin{array}{c}\text { Título } \\
\text { do Rito }\end{array}$ & Tipologia & Breve descrição & $\begin{array}{c}\text { Relação com } \\
\text { a Missa }\end{array}$ & Tip. do Rito & Estrutura \\
\hline $\begin{array}{l}\text { Vol. } 11, \\
\text { Cap. } \\
\text { LXXVIII }\end{array}$ & Jantar & $\begin{array}{l}\text { Jantares } \\
\text { especiais }\end{array}$ & $\begin{array}{l}\text { "Os grandes jantares eram muito raros e só } \\
\text { aconteciam em grandes ocasiões" }\end{array}$ & s/corresp. & s/corresp. & s/corresp. \\
\hline $\begin{array}{l}\text { Vol. } 11, \\
\text { Cap. } \\
\text { LXXVIII }\end{array}$ & $\begin{array}{l}\text { Antes de } \\
\text { dormir }\end{array}$ & $\begin{array}{l}\text { Momento } \\
\text { de reunião }\end{array}$ & $\begin{array}{l}\text { "Ao deixar a mesa, o rei entrrava } \\
\text { imediatamente no seu gabinete. Essa era a } \\
\text { hora de pessoas distintas falarem com ele. } \\
\text { Ele parou na porta por um momento para } \\
\text { ouvir e depois entrou; muito raramente } \\
\text { alguém o seguia, nunca sem pedir permissão } \\
\text { para fazê-lo; e para isso poucos tiveram a } \\
\text { coragem." }\end{array}$ & s/corresp. & s/corresp. & s/corresp. \\
\hline $\begin{array}{l}\text { Vol. } 11, \\
\text { Cap. } \\
\text { LXXVIII }\end{array}$ & $\begin{array}{l}\text { Antes de } \\
\text { dormir }\end{array}$ & $\begin{array}{l}\text { Ida para a } \\
\text { cama }\end{array}$ & $\begin{array}{l}\text { "Depois do jantar, o rei ficou alguns } \\
\text { momentos, de costas para a balaustrada do } \\
\text { pé da cama, rodeado por toda a sua corte" }\end{array}$ & s/corresp. & s/corresp. & $\mathrm{s} /$ corresp. \\
\hline $\begin{array}{l}\text { Vol. } 11, \\
\text { Cap. } \\
\text { LXXVIII }\end{array}$ & $\begin{array}{l}\text { Antes de } \\
\text { dormir }\end{array}$ & Petit Cocher & $\begin{array}{l}\text { "O rei, desejando se aposentar, ia alimentar } \\
\text { os seus cães; depois dizia boa-noite, passou } \\
\text { para o quarto dele, para o 'ruelle' da sua } \\
\text { cama, onde rezava as suas orações, como } \\
\text { pela manhã, e depois se despia. Ele disse } \\
\text { boa noite com uma inclinação da cabeça e, } \\
\text { enquanto todos estavam saindo da sala, ficou } \\
\text { na esquina da lareira, onde ele deu a ordem } \\
\text { ao coronel dos guardas sozinho. Começou } \\
\text { então o chamado "petit coucher", no qual } \\
\text { apenas os especialmente privilegiados } \\
\text { permaneciam. Eles não foram embora até o } \\
\text { Rei se deitar.Então todos partiram curvando- } \\
\text { se pernate o rei. Por dez ou doze anos antes } \\
\text { da sua morte, o 'petit coucher' cessou, em } \\
\text { consequência de um longo ataque de gota.» }\end{array}$ & s/corresp. & $\mathrm{s} /$ corresp. & s/corresp. \\
\hline
\end{tabular}

Quadro 3 - Ritos com base no Missale Romanum ex decreto Sacrosancti Concilii Tridentini.

Tours: Sumptibus et typis Mame (Sacrae Rituum Congregationis Typographorum), 1957.

\begin{tabular}{|c|c|}
\hline Tipologia do Rito & Estrutura \\
\hline Cum lavat manus (Sacerdotalibus paramentis) & Praeparatio ad Missam \\
\hline Ad amictum (Sacerdotalibus paramentis) & Praeparatio ad Missam \\
\hline Ad albam (Sacerdotalibus paramentis) & Praeparatio ad Missam \\
\hline Ad cingulum (Sacerdotalibus paramentis) & Praeparatio ad Missam \\
\hline Ad manipulum (Sacerdotalibus paramentis) & Praeparatio ad Missam \\
\hline Ad stolam (Sacerdotalibus paramentis) & Praeparatio ad Missam \\
\hline Ad casulam (Sacerdotalibus paramentis) & Praeparatio ad Missam \\
\hline Ad caligas (Episcopos Paramentis) & Praeparatio ad Missam \\
\hline Cum exuitur Capa Magna (Sacerdotalibus paramentis) & Praeparatio ad Missam \\
\hline Cum lavat manus (Episcopos Paramentis) & Praeparatio ad Missam \\
\hline Ad amictum (Episcopos Paramentis) & Praeparatio ad Missam \\
\hline Ad Albam (Episcopos Paramentis) & Praeparatio ad Missam \\
\hline Ad cingulum (Episcopos Paramentis) & Praeparatio ad Missam \\
\hline Cum accipit Crucem pectoralem (Episcopos Paramentis) & Praeparatio ad Missam \\
\hline Ad Stolam (Episcopos Paramentis) & Praeparatio ad Missam \\
\hline Ad Tunicellam (Episcopos Paramentis) & Praeparatio ad Missam \\
\hline Ad Dalmaticam (Episcopos Paramentis) & Praeparatio ad Missam \\
\hline Ad Chirothecas (Episcopos Paramentis) & Praeparatio ad Missam \\
\hline Ad Planetam (Episcopos Paramentis) & Praeparatio ad Missam \\
\hline Ad Mitram (Episcopos Paramentis) & Praeparatio ad Missam \\
\hline
\end{tabular}




\begin{tabular}{|c|c|}
\hline Tipologia do Rito & Estrutura \\
\hline Ad anulum (Episcopos Paramentis) & Praeparatio ad Missam \\
\hline Ad manipulum (Episcopos Paramentis) & Praeparatio ad Missam \\
\hline Ad Missa (Sinal da Cruz) & Ante Missa \\
\hline Ad Missa (Salmo 42) & Ante Missa \\
\hline Ad Missa (Confissão) & Ante Missa \\
\hline Ad Missa (Confissão do acólito em nome do povo) & Ante Missa \\
\hline Ad Missa (Subida ao altar do Sacerdote) & Ante Missa \\
\hline Ad Missa (Intóito) & Ante Missa \\
\hline Ad Missa (Kyrie) & Ante Missa \\
\hline Ad Missa (Glória) & Ante Missa \\
\hline Ad Missa (Orações coletas) & Ante Missa \\
\hline Ad Missa (Epístola) & Ante Missa \\
\hline Ad Missa (Grdual, Tracto, Munda cor meum) & Ante Missa \\
\hline Ad Missa (Evangelo) & Ante Missa \\
\hline Ad Missa (Credo) & Ante Missa \\
\hline Ad Missa (Ofertório) & Post Missa \\
\hline Ad Missa (Lavábo) & Post Missa \\
\hline Ad Missa (Oração à Santíssima Trindade) & Post Missa \\
\hline Ad Missa (Oráte Fratres) & Post Missa \\
\hline Ad Missa (Orações secretas) & Post Missa \\
\hline Ad Missa (Prefácio) & Post Missa \\
\hline Ad Missa (Sanctus) & Post Missa \\
\hline Ad Missa (Cânone Romano) & Post Missa \\
\hline Ad Missa (O Pai nosso e o exorcismo) & Post Missa \\
\hline Ad Missa (Orações para a comunhão do sacerdote) & Post Missa \\
\hline Ad Missa (Confíteor dos fiéis) & Post Missa \\
\hline Ad Missa (Ritos da comunhão dos fiéis) & Post Missa \\
\hline Ad Missa (Orações das ablusões) & Post Missa \\
\hline Ad Missa (Antífona da comunhão) & Post Missa \\
\hline Ad Missam (Orações Pós comunhão) & Post Missa \\
\hline Ad Missam (Orações finais e benção dos fiéis) & Post Missa \\
\hline Ad Missam (Último Evangelho) & Post Missa \\
\hline
\end{tabular}

